NBER WORKING PAPER SERIES

\title{
FIVE STEPS TO PLANNING SUCCESS. EXPERIMENTAL EVIDENCE FROM U.S. HOUSEHOLDS
}

\author{
Aileen Heinberg \\ Angela A. Hung \\ Arie Kapteyn \\ Annamaria Lusardi \\ Anya Savikhin Samek \\ Joanne Yoong \\ Working Paper 20203 \\ http://www.nber.org/papers/w20203
NATIONAL BUREAU OF ECONOMIC RESEARCH
1050 Massachusetts Avenue
Cambridge, MA 02138
June 2014

The research reported herein was performed pursuant to a grant from the U.S. Social Security Administration (SSA) funded as part of the Financial Literacy Research Consortium. The authors thank Bart Orriens and Bas Weerman for help with the data, and Phil Martin and participants of the conference "New Insights and Advances in Financial Literacy: Translation, Dissemination, Change," Washington, DC, November 18-19, 2010, for suggestions and comments. The opinions and conclusions expressed herein are solely those of the authors and do not represent the opinions or policy of SSA, or any institution with which the authors are affiliated The views expressed herein are those of the authors and do not necessarily reflect the views of the National Bureau of Economic Research.

At least one co-author has disclosed a financial relationship of potential relevance for this research. Further information is available online at http://www.nber.org/papers/w20203.ack

NBER working papers are circulated for discussion and comment purposes. They have not been peerreviewed or been subject to the review by the NBER Board of Directors that accompanies official NBER publications.

(C) 2014 by Aileen Heinberg, Angela A. Hung, Arie Kapteyn, Annamaria Lusardi, Anya Savikhin Samek, and Joanne Yoong. All rights reserved. Short sections of text, not to exceed two paragraphs, may be quoted without explicit permission provided that full credit, including $\odot$ notice, is given to the source. 
Five Steps to Planning Success. Experimental Evidence from U.S. Households Aileen Heinberg, Angela A. Hung, Arie Kapteyn, Annamaria Lusardi, Anya Savikhin Samek, and Joanne Yoong

NBER Working Paper No. 20203

June 2014

JEL No. D14,D91

\begin{abstract}
While financial knowledge has been linked to improved financial behavior, there is little consensus on the value of financial education, in part because rigorous evaluation of various programs has yielded mixed results. However, given the heterogeneity of financial education programs in the literature, focusing on "generic" financial education can be inappropriate and even misleading. Lusardi (2009) and others argue that pedagogy and delivery matter significantly. In this paper, we design and field a low-cost, easily-replicable financial education program called "Five Steps," covering five basic financial planning concepts that relate to retirement. We conduct a field experiment to evaluate the overall impact of "Five Steps" on a probability sample of the American population. In different treatment arms, we quantify the relative impact of delivering the program through video and narrative formats. Our results show that short videos and narratives (each takes about three minutes) have sizable short-run effects on objective measures of respondent knowledge. Moreover, keeping informational content relatively constant, format has significant effects on other psychological levers of behavioral change: effects on motivation and self-efficacy are significantly higher when videos are used, which ultimately influences knowledge acquisition. Follow-up tests of respondents' knowledge approximately eight months after the interventions suggest that between one-quarter and one-third of the knowledge gains and about one-fifth of the self-efficacy gains persist. Thus, this simple program has effects both in the short run and medium run.
\end{abstract}

Aileen Heinberg
Independent consultant
3025 South Court
Palo Alto, CA 94306
aheinberg@ gmail.com
Angela A. Hung
RAND Corporation
1776 Main Street
Santa Monica, CA 90407
ahung@ rand.org
Arie Kapteyn
University of Southern California
12015 Waterfront Drive
Playa Vista, CA 90094-2536
and NBER
kapteyn@ usc.edu

Aileen Heinberg

3025 South Court

Palo Alto, CA 94306

Angela A. Hung

RAND Corporation

1776 Main Street

Santa Monica, CA 90407

Arie Kapteyn

University of Southern California

Playa Vista, CA 90094-2536

kapteyn@usc.edu

\author{
Annamaria Lusardi \\ The George Washington University \\ School of Business \\ 2201 G Street, NW \\ Duques Hall, Suite 450E \\ Washington, DC 20052 \\ and NBER \\ alusardi@gwu.edu \\ Anya Savikhin Samek \\ University of Wisconsin, Madison \\ 1300 Linden Drive \\ Madison, WI 53706 \\ anyasamek@gmail.com \\ Joanne Yoong \\ National University of Singapore \\ 21 Lower Kent Ridge Road \\ Singapore 119077 \\ joanne_yoong@nuhs.edu.sg
}




\section{Introduction}

In the United States, individuals are increasingly being asked to be in charge of their financial security throughout their lifetime and after retirement. Despite this shift to individual responsibility, many workers are not planning for their retirement (Lusardi, 1999; Lusardi and Beeler, 2007; and Lusardi and Mitchell, 2007, 2009, 2011a,b). Multiple streams of research have linked financial knowledge to better retirement planning and successful wealth accumulation (Lusardi and Mitchell, 2007, 2009, 2011a; Hung et al., 2009; Stango and Zinman, 2009), and a growing body of evidence strongly suggests that the causality runs from financial literacy to behavior rather than the other way around (Lusardi and Mitchell, 2014). While financial knowledge has been convincingly linked to improved financial behavior, basic understanding of economics and finance remains low both among the general population and across age, income, and education levels (Hung, Parker, and Yoong, 2009; Lusardi, Mitchell, and Curto, 2010; Lusardi and Mitchell, 2014).

There is, however, little consensus on the value of financial education, in part because comparative assessment of the gamut of existing programs has yielded mixed results. There is considerable variation in methodology and program types across studies, and, as Lusardi (2008, 2009) and others have argued, pedagogy, intensity, and format may matter significantly in explaining different findings. A key next step is therefore to move beyond a potentially misleading discussion of whether "generic" financial education works, toward an understanding of how to make financial education work through better design and appropriate delivery methods. Bernheim and Garrett (2003) and Bayer, Bernheim, and Scholz (2009) show that programs that only distribute printed material such as newsletters have little effect on participation in retirement savings plans. Duflo and Saez (2003) find relatively small impact from a one-time retirement benefits fair, while both Clark and D'Ambrosio (2008) and Bernheim and Garrett (2003) find some effects on behavior when employers offer single or occasional retirement seminars. However, when seminars are frequent, participation in retirement savings plans does significantly increase (Bernheim and Garrett, 2003). Lusardi and Mitchell (2009) and Bernheim, Garrett, and Maki (2001) find evidence that financial education courses that are a mandated part of formal high school curricula lead to more savings and better retirement planning outcomes in later life. While there is little doubt that financial education done properly can work, the issue of cost-effectiveness remains: with these relatively traditional delivery models, there is a clear tradeoff between efficacy and ease of implementation: Intensive interactive programs are more costly in terms of money and time, may not scale easily, may not be easily accessible by a wider audience and often by design appeal to only a small target demographic.

In this paper, we contribute to resolving this important issue by designing and experimentally evaluating a financial education program called Five Steps that draws on insights from psychology to more effectively deliver information about five core concepts underlying financial planning for retirement. A thriving literature in this field demonstrates the power of behavioral economics to affect households' financial decisions. Benartzi and Thaler (2004) and Ashraf, Karlan, and Yin (2009) build on inertia and the desire for precommitment to design more effective savings products, while Bertrand et al. (2010) use principles of persuasive advertising to motivate a series of advertising content treatments promoting the take-up of consumer credit. 
We apply the same approach to financial education: Five Steps was explicitly developed using psychological principles to increase appeal and motivate behavioral change, while keeping to a format suitable for easy, low-cost replication and mass dissemination.

We use a field experiment to evaluate the overall impact of Five Steps on a probability sample of the American population. In different treatment arms, we quantify the relative impact of delivering the program through video and narrative formats. The results of the paper demonstrate the effectiveness of using simple precepts from psychology and marketing to enhance financial education and the need to take seriously features of program design and delivery beyond simply informative factual content.

The rest of the paper proceeds as follows. Section II describes the economic and psychological theory behind the development of the Five Steps program and the intervention itself, and a conceptual framework for evaluating the effects of the program. Section III details the experimental approach used to evaluate the program. Section IV presents the results of intervention. Section V considers how much of the effects remain in a follow-up test some eight months after the intervention. Section VI discusses implications for future work and concludes.

\section{Conceptual Framework and Program Development}

The effectiveness of a financial education program is normally judged on two levels: whether a program successfully conveys information to its target audience and whether it ultimately leads to behavioral change. In this paper, we focus on the former, but we also consider changes in hypothetical behavior.

Although the financial education literature often recognizes that financial education is a choice made by individuals, the decision processes behind knowledge acquisition are not often studied in great depth. Exposing an individual to a financial education program is by no means a guarantee of take-up - either in terms of actual program participation or (in the case of programs that are mandatory) actual learning conditional on participation. Meier and Sprenger (2013) argue that knowledge is a form of investment, the value of which lies in a positive excess return from financial investing, and that consumers make the decision to participate in financial education based on their perception of this return. Similarly, Delavande, Rohwedder, and Willis (2008) and Lusardi, Michaud, and Mitchell (2013) model the returns to financial knowledge as a higher expected return on financial assets, with the cost of acquiring knowledge being a function of explicit payment and other factors, including inherent cognitive ability and effort.

Consider the following very simple conceptual framework: suppose that an individual has to exert effort $e$ to gain financial knowledge $k$, such that the amount of knowledge gained $k(e)$ and cost of effort $c(e)$ are both increasing in $e$. The expected return to knowledge is $E[U(k)]$ where $U$ is also increasing in $k$. The net expected gain from expending effort is thus $E[U(k(e))]-c(e)$. Under standard assumptions about $U$, an individual will expend effort on financial education until the expected marginal return from the investment in knowledge is equal to the marginal cost of effort of acquiring that knowledge; i.e., $E\left[U^{\prime}(k) k^{\prime}\left(e^{*}\right)\right]=c^{\prime}\left(e^{*}\right)$. 
This simple formulation illustrates three possible ways to make a program more effective for users, in the sense of ultimately increasing the optimal choice of knowledge $k\left(e^{*}\right)$.

- First, a program should be informative, by providing a high marginal return in terms of knowledge gains to a given amount of effort; $k^{\prime}(e)$ should be large.

- Secondly, it should be accessible to the users, i.e., have a low marginal cost to a given amount of effort; $c$ '(e) should be small. We note that this is not only in terms of explicit payment, but also in terms of disutility - programs that are more inherently enjoyable to experience may ultimately lead to more knowledge gain.

- Finally, it should be motivational, i.e., by increasing the returns from acquiring a given amount of knowledge; $U^{\prime}(k)$ should be large. Choosing to deliver knowledge that is highly relevant to individuals (and hence has the potential to provide high returns) should itself be implicitly motivating. However, in practice, the degree of ex-ante awareness among potential participants may not be sufficient. Behavioral economics suggests that motivation can be manipulated in multiple ways. For instance the program can incentivize participants by making utility gains more salient or more easily achievable: educating participants about the true benefits of financial knowledge or even providing direct financial incentives. In their study of advertising campaigns, Bertrand et al. (2010) argue that such effects can also take place through manipulating reference points or cues that increase the marginal utility of consumption, or by biasing other key decision parameters through manipulation of intuitive and/or deliberative cognitive processes, for instance verbally framing a program or including specific visual images that evoke a particular emotional response.

We have designed specific features of a financial education intervention with these three dimensions in mind, as described below.

\section{II.A. Selecting Informative Content}

To ensure that the program is highly informative and likely to result in large benefits to a broad share of the population, we focused the content on five core concepts that underlie successful retirement planning that have previously been identified in the literature as important, persistent basic knowledge gaps (Lusardi and Mitchell, 2014). The literature also suggests that behavioral factors contribute to these gaps. Taking behavioral factors into account, our program aims to improve understanding of the following five core concepts.

\section{- Compound interest:}

Understanding the difference between simple and compound interest, and how quickly interest accumulates can help individuals both appreciate the importance of starting to save early and the dangers of borrowing at very high interest rates. However, people seem to know little about interest compounding (Lusardi, 2012; Lusardi and Mitchell, 2014; Lusardi and Tufano, 2009a, 2009b). Moreover, in what has been termed future value bias (Stango and Zinman, 2009), people tend to underestimate how quickly 
compound interest grows. This is a case of the more general exponential growth bias, in which people underestimate the growth of functions with exponential terms. This bias is strongly correlated with savings, portfolio choices, net worth, and other measures of personal finances.

\section{- Inflation:}

Individuals need to understand the potential reduction in purchasing power over time due to inflation in order to assess saving and borrowing decisions in real rather than nominal terms. This is particularly important given the long horizons typical in planning for retirement. There seems to be little knowledge of the workings of inflation (Lusardi and Mitchell, 2014). Behavioral research also documents money illusion: people tend to think in terms of nominal rather than real monetary values, insufficiently taking into account the impact of inflation (Shafir, Diamond, and Tversky, 1997).

- Risk diversification:

Individuals should not put all of their eggs in one basket, but rather choose welldiversified portfolios and avoid investing in only one asset, particularly if that asset is their employer's company stock. There is very little knowledge about risk diversification (Lusardi and Mitchell, 2014). Understanding of risk diversification seems also influenced by affect and heuristics. For example, people often rate company stock, the stock of their employer, as a safer investment than a diversified fund (Benartzi and Thaler, 2007). Even when spreading assets among several investments, 401(k) investors often choose nä̈ve diversification, with equity exposure tracking the relative number of equity funds in the menu of available funds (Benartzi and Thaler, 2001).

- Tax treatment of retirement savings vehicles:

Retirement assets invested in tax advantaged vehicles such as 401(k)s and IRAs benefit from tax exemptions on contributions, capital gains, or withdrawals, allowing for more rapid potential growth. In fact, people possess limited attention and often do not deliberatively consider and appropriately weight all features of complex decisions. The impact of taxes on decision making therefore does not depend solely on their economic consequences, but also on the salience of these taxes (Congdon, Kling, and Mullainathan 2009).

- Employer matches of defined contribution savings plans:

Many employers match (in different proportion, often one-to-one) the contributions employees make to retirement accounts, resulting in a much higher return on retirement savings. Failure to contribute up to the employer's matching threshold is often the equivalent of leaving money on the table. However, a large portion of individuals do not take advantage of their employer's full 401(k) matching contributions; evidence suggests this cannot be fully attributed to rational strategies. Choi, Laibson, and Madrian (2005) investigated a special case in which it was difficult to provide a normative explanation for 
failure to contribute up to the employer's matching threshold. They examined a group of individuals who could withdraw assets from their $401(\mathrm{k}) \mathrm{s}$ at any time without tax penalties and found that, even among this group, half contributed below the match threshold. Notifying employees about the existence of this matching opportunity in the context of three brief written survey questions did not significantly impact the contribution rate.

\section{II.B. Lowering Behavioral Barriers}

To ensure that the program materials were delivered with low technical and time burden on the user, we designed them to be accessible, engaging, and relatively brief. We also drew on several well-established principles of psychology and marketing to increase motivation.

Guided by Bandura's social cognitive theory (1989), we considered the role of self-efficacy in uptake of our educational program. Self-efficacy refers to the subjective belief that one (rightly or wrongly) has the ability to complete a particular task in a way that will lead to a successful outcome. "Learning self-efficacy," one's belief that one has the capacity to successfully learn from an educational program, increases motivation to utilize such a program. Since individuals are often intimidated by financial information, we took care to make our program accessible in order to increase self-efficacy and, in turn, motivation to utilize the program.

The five financial concepts were embedded in five simple short stories that describe the concepts verbally and present the benefits of taking action. Each story explains elements of one of the financial principles, consists of dialogue between two people, and is written to convey information in a relatively light-hearted, positive manner. Each story focuses on a few simple take-away points related to the concept and we minimize the use of complex jargon.

We adopted a narrative strategy. In commercial advertising, adult education, and public health, narratives are an established means of creating cognitive involvement and emotional immersion (Bruner, 1987; Green and Brock, 2000; Norris et al., 2005; McDaniel, Waddill, and Shakesby, 1996; Davidhizar and Lonser, 2003) and have been shown to outperform argument-based advertisements in improved comprehension for poor readers (Michielutte et al., 1992).

Bandura's account of self-efficacy also informed our use of a narrative strategy. While a main focus of the program was on improving financial knowledge, we also aimed to provide that knowledge in a way that could impact financial behavior. According to social cognitive theory, bolstering self-efficacy beliefs (i.e., one's belief that they can successfully perform a behavior) fosters behavior change. One way self-efficacy beliefs can be strengthened is through observing others successfully perform (or "model") desired tasks and achieve desired outcomes (Bandura, 1989). We created narratives in which characters did just that: they accomplished desired tasks and achieved desired goals, even in the face of challenges. We included triumph over obstacles in the narratives because observing this type of persistence fosters a more resilient sense of selfefficacy. It has been noted that observers are more strongly influenced by others when the observed and observer are similar. Therefore, our stories incorporate a focus on relatable situations and characters. As the content focus of Five Steps is on basic retirement planning rather than catch-up strategies appropriate for those nearing retirement, we designed these 
features to be most relevant to young adults (going out, shopping, newlyweds, workplace experiences) and our videos employed actors between the ages of 20 and 40. By having the models appear relaxed and in an everyday setting and explicitly emphasizing lack of stress in taking action in the scripted dialogue, we tried to make the intervention accessible and unintimidating while at the same time imparting and reinforcing new information. It's worth noting that the use of behavioral modeling itself has been found to decrease anxiety in stressful situations more than purely informational materials alone (Gagliano, 1988).

Our program design also applied other behavioral insights. The literature on present-bias and time-inconsistency documents that people often lack the self-control to take action that will results in future benefits (for review, see Frederick et al., 2002). This can manifest itself as a tendency to procrastinate when it comes to retirement savings or taking up financial education itself, which has largely long-term benefits (Benartzi and Thaler, 2007; Meier and Sprenger, 2009). To counter this, we designed the intervention to emphasize short-term benefits, whether tangible or not (e.g., increased peace of mind), in order to make near-term benefits more salient.

Finally, wherever possible, as related to the individual stories, we employed insights from various aspects of the existing literature. For instance, as research indicates that people perceive free items as especially attractive (Shampanier, Mazar, and Ariely, 2007), when describing 401(k) contributions, employer matches was deliberately framed as "free money."

\section{II.C. Delivery Models: Videos versus Narratives}

As part of this study, we developed and produced our narrative-based materials using two alternative delivery methods: written narratives and videos.

While written materials are usually considered easy to disseminate, the online video increases the potential for efficient and scalable interventions. Online videos are rising in popularity; a 2010 report by the Pew Research Center (Purcell, 2010) found that $69 \%$ of internet users watched or downloaded videos online. The fixed cost of creating videos may be close to the cost of creating written/printed materials. However, with the rise of free Internet video hosting services, the marginal cost of dissemination is rapidly becoming negligible. While many interventions currently rely on written pamphlets and materials, studies of health education have found higher user satisfaction with educational videos as compared to written materials (Jeste et al., 2008; Armstrong et al., 2011). Most importantly, while written narratives provide some degree of behavioral modeling, the direct visual experience provided by videos may have greater potential to provide the type of observational learning experience needed to have an impact on selfefficacy (Gist, 1989). Additionally, education research indicates that videos have the potential to create fertile opportunity for cognitive engagement (Kozma, 1991). As the popularity of online videos is an important potential new development in adult education, we sought to explore the relative impact of providing Five Steps through video versus written formats.

Videos and narratives were carefully matched on both informational content and stories, with the way concepts were explained closely mirrored in the two formats. Each of the five videos was approximately three minutes long. The narratives are reproduced in Appendix B, while the video 
links and titles (made available via YouTube.com, a leading free online video hosting service) are listed in Appendix C.

\section{Field Experiment Approach}

The primary goal of the study was to develop and evaluate an innovative, engaging, and low-cost financial education program. Our empirical methodology employs qualitative and quantitative methods to design and test the effectiveness of the financial education program.

\section{III.A. Qualitative Study Design}

In order to qualitatively test the intervention materials and get feedback, as well as to gain insight on savings attitudes and behavior, we first conducted two focus groups in Washington, DC, with young workers between the ages of 25 and 40. We were particularly interested in young adults' response to our intervention, as starting to apply knowledge of the financial concepts earlier in life could produce the greatest benefit, even though younger adults might consider retirement saving less relevant. The first focus group consisted of ten "savers," people who were already saving for retirement. The second group consisted of eight "non-savers," who were not currently saving for retirement. This stratification allowed participants with similar experiences to feel more comfortable and engage in a useful discussion. Focus group participants were presented with each of the five stories explaining the financial concepts. They were shown two stories in video format only, two stories in written narrative format only, and one story in both video and written narrative formats. After each story, comments and feedback on the interventions were solicited and the groups concluded with a general discussion of the different presentation formats as well as how the information might motivate any behavioral changes.

While the focus group provided us with a deeper understanding of the types of responses we may receive from a small group of savers and non-savers, it did not give us a great deal of understanding of program effectiveness. Thus, we turn to the main empirical strategy in our paper, a field experiment in which we rigorously test the causal effects of the program.

\section{III.B. Field Experiment Design}

To quantitatively test the Five Steps program, we designed a field experiment using the RAND American Life Panel (ALP), fielded from May through November 2010. At the time of the intervention, the ALP consisted of a sample of approximately 3,000 households who are regularly interviewed over the Internet. An advantage relative to most other Internet panels is that the ALP is a probability sample of the US population. ${ }^{1}$ Data routinely collected via the ALP

\footnotetext{
${ }^{1}$ ALP respondents participating in our experiments have been recruited in one of three ways. Most were recruited from among individuals age 18+ who were respondents to the Monthly Survey (MS) of the University of Michigan's Survey Research Center (SRC). A subset of respondents (approximately 500) were recruited through a snowball sample; here respondents were given the opportunity to suggest friends or acquaintances who might also want to participate. Respondents without Internet (both in the Michigan sample and the snowball respondents) were provided with so-called WebTVs (http://www.webtv.com/pc/), which allow them to access the Internet using their television and a telephone line. The technology allows respondents who did not have previous Internet access to participate in the panel and furthermore use the WebTVs for browsing the Internet or using email. A new group of respondents (approximately 500) has been recruited after participating in the National Survey Project, created at
} 
include a wide array of variables about household and individual demographics. In our sample, about $30 \%$ of participants are below the age of $40,55 \%$ are $41-64$ years old, and $15 \%$ are $65+$. The education attainment is rather high - more than $40 \%$ have a college degree - and 59\% are female. About $28 \%$ have income below $\$ 35,000,40 \%$ have income between $\$ 35,000$ and $\$ 75,000$, and $32 \%$ have income above $\$ 75,000$.

In May 2010, all members of the ALP (regardless of age) were administered a baseline survey with a series of questions on topics related to our five concepts: (1) compound interest; (2) inflation; (3) risk diversification; (4) tax treatment of retirement savings vehicles; and (5) employer matches of defined contribution savings plans. The questions are reproduced in Appendix A. While the survey questions are multiple choice, the correct answers to the quizzes are all binary (the answer is correct or incorrect).

Starting in August 2010, with the exception of a control group, respondents were exposed to six successive treatments, each presenting material for one topic in either video or written narrative form. Treatments were delivered over three successive waves of the survey, which were spaced two weeks apart. In order to maintain a reasonable length of each survey session, two treatments were given in each wave.

The randomization was implemented as follows:

- The order of the five topics was randomized with equal probability for all respondents.

- Within each treatment, format was randomized so that respondents would experience either (only) video or (only) written narrative format with equal probability, with one exception.

- In one wave of the survey (randomly selected with equal probability), a respondent would experience two treatments for the same topic, one in video and one in written narrative format (in random order).

- After each treatment, the respondent was again asked the relevant questions from the baseline survey.

- In the same period, respondents allocated to the control group would also again answer questions from the baseline survey.

The effective result of this design was that every respondent was exposed to each of the five topics in random order, and for every topic but one was exposed to either video (only) or

Stanford University with SRBI. This sample was recruited in person, and at the end of their one-year participation, participants were asked whether they were interested in joining the RAND American Life Panel. Most of these respondents were given a laptop and broadband Internet access. For more information about the ALP sample recruiting methodology as well as access to the data collected in the ALP to date, the reader is referred to http://mmic.rand.org. 
narrative (only) format. For one randomly chosen topic, the respondent saw both the video and the written narrative. Importantly, respondents could not opt to receive a certain intervention.

The benefits of the randomization design lie in the power of causal inference. When estimating average effects of the program by topic and format, we are able to pool the data, regardless of wave and treatment sequence. To estimate the program effect, we can use a simple comparison of means that captures a differences-in-differences (DID) approach, in which changes in correct answers of the respondents exposed to videos or narratives (the treatment group) are compared to changes in answers in the control group.

In April 2011, the same quiz was administered again to all experiment participants, both treatment and control groups. Below, we discuss the short-run results. In Section V, we discuss the results of the 2011 follow-up test.

\section{Results}

\section{IV.A Qualitative Focus Group Responses}

Both the savers and non-savers described the program's level of content difficulty as appropriate for themselves. The non-saver group found more of the information new, while savers found that the intervention reinforced and supplemented knowledge of concepts with which they were already somewhat familiar. Overall, group participants described themselves as not intimidated by the program and also did not feel as though it talked down to them. The saver and non-saver groups expressed fairly similar thoughts on format differences. Some expressed keener interest in the videos as they did not require the work of reading, while others noted that they preferred having access to both formats. No one argued for written narratives alone. ${ }^{2}$ Unprompted, focus group participants also described specific actions they planned to take as a result of viewing the videos, but no such plans were voiced as a result of interacting with the written narratives. ${ }^{3}$

\section{IV.B Field Experiment Results}

Table 1 shows the percentage of correct answers to each of the questions at baseline (May 2010). Average baseline knowledge of these concepts varied significantly, with correct responses to some of the questions falling below $50 \%$. However, $92 \%$ of respondents were able to answer the first question on compound interest correctly.

Table 1 further breaks down responses by gender, education, age, and income. More men answered questions correctly than women on every question at baseline, confirming the results of many other surveys on financial literacy (Lusardi and Mitchell, 2014). Similarly, respondents

\footnotetext{
${ }^{2}$ Some in the saver group suggested that the videos were more motivating and inspired them to take action. In response to the videos, one focus group members said, "That made me want to run out and invest some money." Another said that the videos were "ready for television! Gonna be like, 'Man, I need to start investing!' People will definitely react to that."

${ }^{3}$ One described starting a new job several months before and said, "I haven't gotten around to filling out the 401(k) forms...I will be filling out those forms tomorrow." Another said, "Last year I got a new nephew and a godson so I think that I'll open an account for each of them to begin the compound interest."
} 
age 18-40 performed worse than those age 41-64 and worse than those age 65 and older on all but two questions, again consistent with related research (Lusardi, Mitchell, and Curto, 2010; Lusardi and Mitchell, 2014). On every question, those with incomes below $\$ 35,000$ performed more poorly than those with incomes between $\$ 35,000$ and $\$ 75,000$, who in turn performed more poorly than respondents earning $\$ 75,000$ and above. The same pattern was found for education; respondents with high school diplomas or less performed more poorly on each question than respondents who attended some college, who in turn performed more poorly than those with college diplomas, as has been found to be the case in other work (Lusardi and Mitchell, 2014).

Table 2 shows the numbers of each treatment that were administered during each wave, by topic and medium (narrative or video). Wave 1 went to field in August 2010 and the surveys were closed on November 3, 2010. ${ }^{4}$ Each written narrative / video was seen alone by between 1,427 and 1,497 respondents, while each topic was administered in the double format consisting of both the narrative and the video to between 1,017 and 1,082 respondents.

\section{A Quantitative Findings}

Tables $3 \mathrm{~A}$ and $3 \mathrm{~B}$ present a summary of performance in each of the five topic areas for the entire sample of respondents, aggregated across individual survey questions. ${ }^{5}$ Table $3 \mathrm{~A}$ shows the results for objective knowledge questions (in terms of average percentage correct answers) and Table 3B shows the results for the self-efficacy questions (in terms of average self-efficacy score on a scale of 1-5, with 1 being the highest). The table shows a summary of the difference in difference treatment effect estimates (comparison of the mean changes in the treatment group and the mean changes in the control).

The column head "Any Treatment" shows means for all respondents presented with an intervention, including those who saw the video, read the narrative, or did both. The column headed "Video only" refers to respondents who have only seen a video on a particular topic; similarly the heading "Narrative only" signifies that a respondent has only read a narrative about the topic. "Both" indicates that a respondent has been exposed to both a video and a narrative about the topic.

Table 3A shows a number of significant positive treatment effects on objective knowledge questions, across all topics. In general, for questions on which baseline knowledge was high (interest compounding/numeracy and both inflation questions) the program had least effect, while for a topic on which baseline knowledge was modest (tax treatment of DC plans) we observe consistently large treatment effects. Insignificant results are found for inflation and one

\footnotetext{
${ }^{4}$ In principle, respondents can answer questions whenever it is convenient for them. Typically most respondents reply within the first two weeks of a field period. After two weeks a reminder is sent by email to those who have not responded yet. This procedure is repeated four weeks after a survey goes to field. Generally, there is no reason to "close" a survey, so that, for instance, even after six weeks responses still trickle in. In our experiment, two weeks after a respondent has answered the first wave, he or she becomes eligible for the second wave; two weeks after answering the second wave he or she becomes eligible for the third wave. Thus depending on when respondents respond a wave, they get asked to do a next wave. We kept waves in the field until November 3, 2010.

${ }^{5}$ More extensive results are presented in Appendix tables 1A and 1B.
} 
employer match question, but in the first case results are somewhat inconsistent across format types and questions; in the second case, no effects are significant.

Overall, Table 3A also shows that video-only treatments result in somewhat more positive effects than narrative-only treatments, but interestingly, one does not seem to strictly dominate the other for all questions. Also interestingly and perhaps contrary to the focus group input, being exposed to both treatments does not seem to strictly dominate showing only videos or only written narratives.

Table 3B shows that the overall effects on self-efficacy appear to be positive and significant across all topics, with the largest gains related to tax-treatment of DC plans and employer matches. However, format effects in this case are particularly interesting. In the area of selfefficacy, we clearly see that video appears to be more effective and consistently positive. For the written narratives, the effects are significantly weaker. Showing both videos and narratives has a significantly stronger effect on self-efficacy than only showing the narrative. The comparison between showing video only or both video and narrative does not exhibit a clear pattern.

In general, the findings of our analysis indicate that Five Steps can effectively deliver knowledge and increase self-efficacy. The general results also support the hypothesis that video format can have larger effects on self-efficacy.

To save space we concentrate from now on the proportion of correct answers by domain. Furthermore, since in the next section we will present results for the second test, in April 2011, it is convenient to indicate outcome variables as follows: $Y_{0}$ if outcomes refer to baseline measures; $Y_{1}$ for outcomes obtained immediately after the intervention; $Y_{2}$ for outcomes obtained in the April 2012 follow up.

Table 4 presents treatment effects after controlling for background characteristics. Not surprisingly, a respondent's score on the quiz after the intervention is strongly related to his or her baseline knowledge. Nevertheless the table confirms the findings shown in Table 3 . With the possible exception of inflation, the interventions yielded a highly significant improvement in knowledge of basic financial concepts.

Table 5 reports the findings of regressing the change in the percentage of correct answers on the various treatments and background characteristics. Apart from again showing highly significant effects of the interventions (with the exception of inflation), it also allows us to examine the hypothesis that behavioral modeling works best when subjects are similar to the models presented. It should be recalled that the content and modeling was targeted specifically at the 1840 age group, a fact that would be made more salient in the videos where only actors in this age group were shown. There is indeed some weak evidence consistent with this hypothesis. Compared to the 18-40 group, the 65+ group shows a negative coefficient for four out of five dimensions, with one of these strongly significant (employer match). The remaining characteristics do not appear to have had much of an impact on the effectiveness of the intervention, with the exception of gender. Women show significantly more improvement in knowledge than men for all dimensions, except inflation. We have also tested for interactions between age and the different treatments. Findings are not reported here due to space constraints but can be summarized as follows: Significant interactions are only found for the risk 
diversification dimension, where generally the effects are stronger for younger respondents and weaker for the $65+$ category.

Tables 6 and 7 repeat the analysis of Tables 4 and 5 for self-efficacy. Self-efficacy improves in all dimensions and for all treatments, although the videos appear to be most effective, as observed before. The oldest group shows the smallest gain in self-efficacy, while females appear to gain more than men, and higher incomes more than lower incomes. As with the knowledge question, we have also tested for interactions between age and the different treatments. The results (not reported) show no significant interactions.

\section{The Follow Up Eight Months Later}

As of April 8, 2011, the participants in the experiment (both in the treatment and the control groups) were asked to once again take the same quiz. This allows us to investigate to what extent the positive effects found right after the intervention remain after some passage of time. Tables 8 and 9 are similar to Tables 5 and 7. Now, however, the dependent variable in each regression is the difference in percentage correct between baseline and April $2011\left(Y_{2}-Y_{0}\right)$. It is immediately clear that far fewer treatment effects are significantly different from zero than when measured right after the intervention. Table 8 suggests that the video treatment has the greatest lasting effect: four out of five dimensions show significant effects, while for the narrative treatment only two out of five treatments are statistically significant. Interestingly the video with narrative treatment is never significant. The various background characteristics are generally insignificant.

Table 9 exhibits a pattern that is qualitatively similar to Table 8 . The video treatment is more often significant (three out of five) than the narrative treatment (two out of five). Age interactions are all insignificant (not reported).

Thus, the positive effects immediately after the intervention have worn off over time. Table 10 provides a direct comparison between the short-run effects $\left(Y_{1}-Y_{0}\right)$ and the longer-run effects $\left(Y_{2^{-}}\right.$ $\left.Y_{0}\right)$. As a simple way to gauge how much of the initial effect remain, we also present $\left(Y_{2}-Y_{0}\right) /\left(Y_{1^{-}}\right.$ $Y_{0}$ ). For knowledge questions, the percentage of the initial effect that remains after about eight months is on the order of one-third to one-quarter. For inflation the percentages are larger, but in view of the fact that the initial effect was small for this dimension, we should probably discount this. For the self-efficacy question, only about $10-20 \%$ remains.

These finding suggests the need for regular updating of subjects' knowledge with new material, to avoid quick depreciation of newly gained knowledge.

\section{Discussion and Future Work}

In this paper, we designed and evaluated a financial education program that demonstrably increased participants' objective knowledge and self-efficacy. Importantly, our field experiment approach allowed us to conclude that the improvements we saw in the treatment groups were caused by the Five Steps program or by the particular format tested. Our results show that given the very minimal time respondents spent watching the videos or reading the narratives (each of 
the videos or narratives takes about three minutes), Five Steps has sizable short-run effects on objective measures of respondent knowledge. Moreover, keeping informative content relatively constant, format has significant effects on other psychological levers of behavioral change: effects on motivation and self-efficacy are significantly higher when videos are used, which ultimately influence knowledge acquisition.

It is important to reiterate that the experiment at this stage measures only outcomes related to objective knowledge and self-efficacy. The focus group discussions suggest that in general, the written narratives may promote knowledge retention but videos may more strongly motivate action and behavior change; this remains a possibility to be tested in future work. Ultimately, the goal of this study is to examine effects on behavior, with outcomes to be collected in a follow-up survey. Empirical findings suggest that self-efficacy and behavior are related, although the causal relationships are not well-established: measures of self-efficacy have been found to be correlated with health behavior (e.g., Kreuter et al., 1999; Strecher et al., 1986; Gillis, 1993; Holden, 1991) as well as in other domains (Stajkovic and Luthans, 1998), including finance (Gutter, Copur, and Garrison, 2009). There is some evidence that suggests financial education programs can increase financial self-efficacy, and ultimately behavioral change (e.g., Sanders et al., 2007; Shockey and Seiling, 2004).

In general, the program presented is an example of how field experiments can contribute to better understanding of the effectiveness of financial literacy interventions. As noted in the introduction, part of the reason for the mixed results in related work is the lack of rigorous evaluation. Field experiments are an ideal policy tool for gaining causal inference in this, as well as in other domains. Future work should focus on using field experiments to investigate which components of educational interventions are most effective. 


\section{References}

Armstrong, April W., Nayla Z. Idriss, and Randie H. Kim (2011), "Effects of video-based, online education on behavioral and knowledge outcomes in sunscreen use: a randomized controlled trial." Patient Education and Counseling 83(2): 273-277.Ashraf, Nava, Dean Karlan, and Wesley Yin (2009), "Female empowerment: Impact of a commitment savings product in the Phillipines." World Development 38: 333-344.

Bandura, Albert (1989), "Human agency in social cognitive theory." American Psychologist, 44(9): 1175-1184.

Bayer, Patrick, Douglas Bernheim and John Karl Sholz (2009), "The effects of financial education in the workplace: Evidence from a survey of employers." Economic Inquiry, 47(4): 605-624

Benartzi, Shlomo, and Richard H. Thaler (2001), "Naive diversification strategies in retirement saving plans." American Economic Review, 91(1): 79-98.

Benartzi, Shlomo, and Richard H. Thaler (2004), "Save More Tomorrow: Using behavioral economics to increase employee savings." Journal of Political Economy 112.1, Part 2, pp. S164-S187.

Benartzi, Shlomo, and Richard H. Thaler (2007), "Heuristics and biases in retirement savings behavior." Journal of Economic Perspectives 21(3): 81-104.

Bernheim, B. Douglas, and Daniel M. Garrett (2003), "The effects of financial education in the workplace: evidence from a survey of households." Journal of Public Economics 87(7): 1487-1519.

Bernheim, B. Douglas, Daniel M. Garrett, and Dean M. Maki (2001), "Education and saving: The long-term effects of high school financial curriculum mandates." Journal of Public Economics 80(3): 435-465.

Bertrand Marianne, Dean Karlan, Sendhil Mullainathan, Eldar Shafir and Jonathan Zinman (2010), "What's advertising content worth? Evidence from a consumer credit marketing field experiment," Quarterly Journal of Economics, 125: 263-305

Bruner, Jerome (1987), "Life as narrative." Social Research 54(1): 11-32.

Campbell, John (2006), “Household finance," Journal of Finance 61, pp.15531604.

Choi, James J., David Laibson, and Brigitte C. Madrian. (2005), "\$100 Bills on the Sidewalk: Suboptimal Saving in 401(k) Savings Plans." NBER Working Paper 11554.

Clark and D'Ambrosio (2008), Adjusting retirement goals and saving behavior The role of financial education in A. Lusardi (ed.). Overcoming the Saving Slump: How to Increase the Effectiveness of Financial Education and Saving Programs, Chicago: University of Chicago Press, 237-256.

Congdon, William, Jeffrey R. Kling, and Sendhil Mullainathan (2009), "Behavioral economics and tax policy." National Bureau of Economic Research Working Paper No. 15328.

Davidhizar, Ruth, and Giny Lonser (2003), "Storytelling as a teaching technique." Nurse Educator 28(5): 217-221. 
Delavande, Adeline, Susann Rohwedder, and Robert Willis (2008), Preparation for retirement, financial knowledge and cognitive resources. MRRC Working Paper Series 190.

Duflo, Esther, and Emmanuel Saez (2003), The role of information and social interactions in retirement plan decisions: Evidence from a randomized experiment. Quarterly Journal of Economics, 118: 815-842.

Frederick, Shane, George Loewenstein, and Ted O'Donoghue (2002). "Time discounting and time preference: a critical review." Journal of Economic Literature. 40: 351-401.

Gagliano, M. E. (1988), "A literature review on the efficacy of video in patient education." Academic Medicine 63(10): 785-792.Gillis, Angela (1993), "Determinants of a health-promoting lifestyle: An integrative Review," Journal of Advanced Nursing 18: 345-353.

Gist, Marilyn E. (1989), "The influence of training method on self-efficacy and idea generation among managers." Personnel Psychology 42(4): 787-805.

Green, M. C., and T. C. Brock (2000), "The role of transportation in the persuasiveness of public narratives." Journal of Personality and Social Psychology 79(5): 701-721.Gutter, Michael, Zeynep Copur, and Selena Garrison (2009), "Which Students are More Likely to Experience Financial Socialization Opportunities? Exploring the Relationship Between Financial Behaviors and Financial Well-Being of College Students." Networks Financial Institute Working Paper 2009-WP: 07.

Holden, Gary (1991), "The relationship of self-efficacy appraisals to subsequent health related outcomes: A meta- analysis," Social Work in Health Care 16: 53-93.

Hung, Angela A., Andrew M. Parker, and Joanne K. Yoong (2009), "Defining and measuring financial literacy." RAND Working Paper, no. WR-708.

Hung, Angela A., Erik Meijer, Kata Mihaly, and Joanne K. Yoong (2009), "Building Up, Spending Down: Financial Literacy, Retirement Savings Management, and Decumulation." RAND Working Paper No. WR-712.

Jeste, D. V., L. B. Dunn, D. P. Folsom, and D. Zisook (2008), "Multimedia educational aids for improving consumer knowledge about illness management and treatment decisions: a review of randomized controlled trials." Journal of Psychiatric Research 42(1): 1-21.Kozma, Robert (1991). "Learning with Media," Review of Educational Research Summer 61(2): 179-211.

Kreuter et al., (1999), M. W., Strecher, V. J., \& Glassman, B. (1999), One size does not fit all: the case for tailoring print materials. Annals of behavioral medicine, 21(4): 276-283.

Lusardi, Annamaria (1999), "Information, Expectations, and Savings for Retirement," in Henry Aaron (ed.), Behavioral Dimensions of Retirement Economics, Washington, D.C.: Brookings Institution Press and Russell Sage Foundation, 81-115.

Lusardi, Annamaria (2008), "Financial Literacy: An Essential Tool for Informed Consumer Choice?" Working Paper, Joint Center for Housing Studies, Harvard University. 
Lusardi, Annamaria, (2009), "U.S. Household Savings Behavior: The Role of Financial Literacy, Information and Financial Education Programs," in C. Foote, L. Goette, and S. Meier (eds.), Policymaking Insights from Behavioral Economics, Federal Reserve Bank of Boston, 109-149.

Lusardi, Annamaria (2010), “Americans' Financial Capability," mimeo, Dartmouth College.

Lusardi, Annamaria (2012), Numeracy, Financial Literacy, and Financial Decision-Making," Numeracy, 5(1), Article 2, January 2012.

Lusardi, Annamaria and Jason Beeler (2007), "Saving Between Cohorts: The Role of Planning," in B. Madrian, O. Mitchell, and B. Soldo (eds.), Redefining Retirement: How Will Boomers Fare? Oxford University Press, Oxford, 2007, pp. 271-295.

Lusardi, Annamaria, Pierre-Carl Michaud, and Olivia S. Mitchell (2013), Optimal Financial Literacy and Wealth Inequality. NBER Working Paper 18669.

Lusardi, Annamaria, and Olivia S. Mitchell (2007), "Baby Boomer Retirement Security: The Role of Planning, Financial Literacy, and Housing Wealth," Journal of Monetary Economics 54: 205-224.

Lusardi, Annamaria, and Olivia Mitchell (2008), "Planning and Financial Literacy. How Do Women Fare?" American Economic Review, 98(2): 413-417.

Lusardi, Annamaria, and Olivia Mitchell (2009), "How Ordinary Consumers Make Complex Economic Decisions: Financial Literacy and Retirement Readiness," NBER Working Paper n. 15350.

Lusardi, A., and O. S. Mitchell (2011a). "Financial Literacy and Planning: Implications for Retirement Wellbeing." In Financial Literacy: Implications for Retirement Security and the Financial Marketplace, O. S. Mitchell and A. Lusardi (eds.). Oxford, UK: Oxford University Press, 2011: 17-39

Lusardi, Annamaria, and Olivia S. Mitchell (2011b). "Financial Literacy and Retirement Planning in the United States." Journal of Pension Economics and Finance 10: 509-525.

Lusardi, Annamaria, and Olivia S. Mitchell (2014). "The Economic Importance of Financial Literacy: Theory and Evidence." Journal of Economic Literature 52(1): 5-44

Lusardi, Annamaria, Olivia Mitchell, and Vilsa Curto (2010), "Financial Literacy Among the Young," Journal of Consumer Affairs, 44(2): 358-380.

Lusardi, Annamaria, and Peter Tufano (2009a), "Debt Literacy, Financial Experiences, and Overindebtedness," NBER Working Paper n. 14808.

Lusardi, Annamaria, and Peter Tufano (2009b), "Teach Workers about the Peril of Debt," Harvard Business Review, November, pp. 22-24.

McDaniel, M. A., P. J. Waddill, and P. S. Shakesby (1996), "Study strategies, interest, and learning from text: The application of material appropriate processing." In D. Hermann, C. McEvoy, C. Hertzog, P. Hertel, and M. Johnson (Eds.), Basic and applied memory research: Theory in context. vol. 1 (pp. 385-397). Mahwah, NJ: Erlbaum.

Meier Stephan and Charles Sprenger (2013), Discounting financial literacy: Time 
preferences and participation in financial education programs, Journal of Economic Behavior and Organization 95: 159-174.

Michielutte, Robert, Judy Bahnson, Mark B. Dignan, and Elissa M. Schroeder (1992), "The use of illustrations and narrative text style to improve readability of a health education brochure." Journal of Cancer Education 7(3): 251-260.

Norris, Stephen P., Sandra M. Guilbert, Martha L. Smith, Shahram Hakimelahi, and Linda M. Phillips (2005), "A theoretical framework for narrative explanation in science." Science Education 89(4): 535-563.

Organization for Economic Co-operation and Development (2005), Improving Financial Literacy: Analysis of Issues and Policies, Paris, France.

Purcell, Kristen (2010). The State of Online Video. Pew Internet \& American Life Project.

Sanders, C. K., T. L. Weaver, and M. Schnabel (2007), "Economic Education for Battered Women: An Evaluation of Outcomes." Affilia 22(3): 240-254.

Shafir, Eldar, Peter Diamond, and Amos Tversky (1997), "Money Illusion," Quarterly Journal of Economics, CXII(2): 341-374.

Shampanier, Kristina, Nina Mazar, and Dan Ariely (2007), "Zero as a Special Price: The True Value of Free Products.” Marketing Science 26(6): 742757.

Shockey, Susan S., and Sharon B. Seiling (2004), "Moving into action: Application of the transtheoretical model of behavior change to financial education." Financial Counseling and Planning 15(1): 41-52.

Stajkovic, Alexander, and Fred Luthans (1998), "Self-efficacy and work-related performance: A metaanalysis," Psychological Bulletin 124: 240-261.

Stango, Victor, and Jonathan Zinman (2009), "Exponential Growth Bias and Household Finance," Journal of Finance 64: 2807-2849.

Strecher, V. J., B. M. DeVellis, M. H. Becker, and I. M. Rosenstock (1986), “The role of self-efficacy in achieving health behavior change." Health Education \& Behavior 13(1): 73-92.

Yoong, Joanne (2011), "Financial illiteracy and stock market participation: Evidence from the RAND American Life Panel," in Financial Literacy: Implications for Retirement Security and the Financial Marketplace, edited by O. S. Mitchell and A. Lusardi, Oxford University Press, Oxford, UK: pp. 76-100. 
Table 1: Percentage of correct responses to each question at baseline by gender, age, income, and education $\left(\mathrm{Y}_{0}\right)$.

\begin{tabular}{|c|c|c|c|c|c|c|c|c|c|c|c|c|}
\hline \multirow[t]{2}{*}{ Questi } & \multirow[t]{2}{*}{ All } & \multicolumn{2}{|c|}{ Gender } & \multicolumn{3}{|c|}{ Age } & \multicolumn{3}{|c|}{ Income } & \multicolumn{3}{|c|}{ Education } \\
\hline & & M & $\mathrm{F}$ & $\begin{array}{c}18- \\
40\end{array}$ & $\begin{array}{c}41- \\
64\end{array}$ & $65+$ & $\begin{array}{c}<\$ 35 \\
\mathrm{k}\end{array}$ & $\begin{array}{c}>\$ 35 \\
\mathrm{k}\end{array}$ & $\begin{array}{c}>\$ 75 \\
\mathrm{k}\end{array}$ & $\begin{array}{l}\text { HS } \\
\text { or }\end{array}$ & $\begin{array}{l}\text { Some } \\
\text { College }\end{array}$ & $\begin{array}{l}\text { Colle } \\
\text { ge }\end{array}$ \\
\hline \multicolumn{13}{|c|}{ A. Compound Interest } \\
\hline $\mathrm{CI} 2$ & 91.66 & 94.8 & 89.4 & 87.3 & 92.7 & 95.1 & 85.0 & 92.8 & 95.5 & 83.4 & 90.63 & 96.59 \\
\hline CI3 & 65.74 & 74.7 & 59.6 & 61.8 & 66.3 & 70.1 & 56.2 & 64.1 & 75.6 & 53.4 & 61.22 & 75.93 \\
\hline CI4 & 71.10 & 81.7 & 63.7 & 65.5 & 72.6 & 75.0 & 57.4 & 71.4 & 81.9 & 52.2 & 66.48 & 84.49 \\
\hline CI5 & 79.05 & 84.2 & 75.4 & 71.9 & 80.9 & 84.3 & 66.7 & 79.0 & 89.3 & 65.4 & 77.18 & 87.36 \\
\hline \multicolumn{13}{|c|}{ B. Inflation } \\
\hline $\mathrm{I} 2$ & 79.91 & 81.7 & 78.6 & 78.3 & 80.5 & 80.4 & 74.2 & 79.5 & 85.0 & 73.0 & 78.47 & 84.59 \\
\hline I3 & 74.00 & 77.5 & 71.5 & 72.9 & 75.8 & 69.4 & 63.7 & 72.3 & 84.6 & 61.7 & 71.40 & 82.32 \\
\hline \multicolumn{13}{|c|}{ C. Risk Diversification } \\
\hline RD2 & 73.67 & 80.1 & 69.1 & 63.2 & 77.6 & 77.6 & 62.2 & 75.7 & 80.5 & 62.6 & 71.10 & 81.39 \\
\hline RD3 & 72.71 & 82.5 & 65.9 & 62.6 & 76.1 & 77.8 & 57.2 & 73.7 & 84.3 & 54.4 & 67.90 & 86.02 \\
\hline RD4 & 78.29 & 87.0 & 72.2 & 65.0 & 81.8 & 88.4 & 64.5 & 78.4 & 89.4 & 62.7 & 74.89 & 88.93 \\
\hline \multicolumn{13}{|c|}{ D. Tax-Favored Assets } \\
\hline TF2 & 59.60 & 69.9 & 56.5 & 47.1 & 63.4 & 67.3 & 43.3 & 60.9 & 71.2 & 49.3 & 53.55 & 70.22 \\
\hline TF4 & 43.20 & 46.4 & 40.9 & 36.3 & 45.5 & 46.7 & 38.1 & 44.0 & 46.5 & 34.8 & 42.14 & 48.19 \\
\hline TF5 & 48.74 & 58.6 & 41.9 & 34.3 & 53.9 & 55.0 & 31.3 & 45.8 & 67.0 & 33.4 & 39.93 & 64.30 \\
\hline TF6 & 65.60 & 72.5 & 60.8 & 50.6 & 71.4 & 70.9 & 48.6 & 65.4 & 79.6 & 50.6 & 62.34 & 75.85 \\
\hline \multicolumn{13}{|c|}{ E. Employer Match } \\
\hline EM2 & 46.35 & 55.9 & 39.7 & 40.6 & 48.1 & 49.7 & 32.0 & 45.2 & 59.8 & 33.3 & 39.93 & 58.65 \\
\hline EM3 & 45.86 & 50.7 & 42.4 & 45.0 & 46.8 & 43.9 & 32.6 & 46.7 & 55.5 & 33.3 & 41.05 & 56.42 \\
\hline EM4 & 70.70 & 77.2 & 66.0 & 62.4 & 74.1 & 72.9 & 56.3 & 71.0 & 82.1 & 55.7 & 67.94 & 80.43 \\
\hline EM5 & 81.87 & 86.4 & 78.6 & 70.3 & 85.9 & 87.4 & 68.3 & 82.4 & 92.1 & 71.0 & 79.56 & 89.25 \\
\hline
\end{tabular}


Table 2: Interventions, by medium and topic.

\begin{tabular}{ccc}
\hline Medium & Topic & Number of Observations across All Waves \\
\hline Video (only) & Compound Interest & 1462 \\
& Inflation & 1444 \\
& Risk Diversification & 1474 \\
& Tax-Favored Assets & 1447 \\
& Employer Match & 1455 \\
\hline Narrative (only) & Compound Interest & 1497 \\
& Inflation & 1497 \\
& Risk Diversification & 1427 \\
& Tax-Favored Assets & 1447 \\
Eideo \& & Employer Match & 1470 \\
\hline Narrative & Compound Interest & 1017 \\
& Inflation & 1035 \\
& Risk Diversification & 1075 \\
Control Group & Tax-Favored Assets & 1082 \\
& Employer Match & 1051 \\
\hline
\end{tabular}

Note: Total number of respondents equals 2,920. 
Table 3A: DID estimates of treatment effects on the percent of knowledge questions correct by topic $\left(\mathrm{Y}_{1}-\mathrm{Y}_{0}\right)$.

\begin{tabular}{|c|c|c|c|c|c|c|c|c|}
\hline Question & Any Tx & & Video Only & & Narrative On & & Both & \\
\hline \multicolumn{9}{|c|}{ A. Compound Interest } \\
\hline $\mathrm{CI} 2$ & 1.1 & & -0.19 & & 0.61 & \multirow{4}{*}{$*$} & 0.96 & \multirow{4}{*}{$*$} \\
\hline $\mathrm{CI} 3$ & 17.9 & $* *$ & 8.32 & $* *$ & 4.12 & & 6.2 & \\
\hline CI4 & 6.54 & $* *$ & 6.31 & $* *$ & -2.85 & & 4.4 & \\
\hline CI5 & 8.05 & $* *$ & 4.98 & $* *$ & 2.31 & & -0.31 & \\
\hline \multicolumn{9}{|l|}{ B. Inflation } \\
\hline $\mathrm{I} 2$ & -1.19 & & 5.06 & \multirow[t]{2}{*}{$* *$} & -6.44 & \multirow[t]{2}{*}{$* *$} & 1.05 & \\
\hline $\mathrm{I} 3$ & 3.62 & & 3.46 & & -0.67 & & 0.85 & \\
\hline \multicolumn{9}{|c|}{ C. Risk Diversification } \\
\hline RD2 & 9.67 & $* *$ & 3.16 & \multirow{3}{*}{$* *$} & 0.62 & & 7.64 & \multirow[t]{3}{*}{$* *$} \\
\hline RD3 & 12.4 & $* *$ & 6.04 & & 3.18 & & 2.93 & \\
\hline RD4 & 7.03 & $* *$ & 1.38 & & 4.97 & $* *$ & 0.02 & \\
\hline \multicolumn{9}{|c|}{ D. Tax-Favored Assets } \\
\hline TF2 & 14.3 & $* *$ & 7.26 & \multirow[t]{2}{*}{$* *$} & 1.57 & \multirow{3}{*}{$*$} & 6.08 & * \\
\hline TF4 & 14.7 & $* *$ & 3.72 & & 5.34 & & 6.28 & * \\
\hline TF5 & 17.9 & $* *$ & 7.54 & \multirow[t]{2}{*}{$* *$} & 2.78 & & 8.77 & \multirow[t]{2}{*}{$* *$} \\
\hline TF6 & 10.8 & $* *$ & 3.54 & & 4.98 & $* *$ & 1.8 & \\
\hline \multicolumn{9}{|c|}{ E. Employer Match } \\
\hline EM2 & 14.4 & $* *$ & 3.59 & \multirow{4}{*}{$*$} & 3.17 & & 9.86 & \multirow[t]{4}{*}{$* *$} \\
\hline EM3 & -3.82 & & -0.81 & & -1.91 & & -1.02 & \\
\hline EM4 & 8.77 & $* *$ & 3.7 & & 2.31 & & 2.78 & \\
\hline EM5 & 5.55 & $* *$ & 1.43 & & 2.49 & & 1.55 & \\
\hline
\end{tabular}

$* \mathrm{p}<0.1 ; * \mathrm{p}<.05$

Table 3B: DID estimates of treatment effects on self-efficacy by topic [ $1=$ highest, $5=$ lowest; entries are effects times 100] $\left(\mathrm{Y}_{1}-\mathrm{Y}_{0}\right)$.

Summary of DID estimates: Point differences between treatment and controls

$\begin{array}{llll}\text { Any Tx } & \text { Video Only } & \text { Narrative Only }\end{array}$

\begin{tabular}{|c|c|c|c|c|c|c|c|c|}
\hline Compound Interest & -50.4 & $* *$ & -36 & ** & 11.2 & ** & -36.1 & $* *$ \\
\hline Inflation & -50.1 & $* *$ & -43.8 & $* *$ & 5.89 & & -12.9 & $* *$ \\
\hline Risk Diversification & -53.5 & ** & -24.7 & $* *$ & -5.12 & & -28.7 & ** \\
\hline Task-Favored Assets & -82.4 & $* *$ & -36.3 & $* *$ & -7.8 & & -46 & $* *$ \\
\hline Employer Match & -92.7 & ** & -37.7 & $* *$ & -20.1 & ** & -39.4 & ** \\
\hline
\end{tabular}

$* \mathrm{p}<0.1 ; * \mathrm{p}<.05$ 
Table 4: Treatment regressions explaining proportion of correct answers by domain $\left(\mathrm{Y}_{1}\right)$.

\begin{tabular}{|c|c|c|c|c|c|}
\hline & $\begin{array}{c}(1) \\
\text { Compound } \\
\text { Interest }\end{array}$ & $\begin{array}{c}(2) \\
\text { Inflation }\end{array}$ & $\begin{array}{c}(3) \\
\text { Risk } \\
\text { Diversification }\end{array}$ & $\begin{array}{c}\text { (4) } \\
\text { Tax-Favored } \\
\text { Assets }\end{array}$ & $\begin{array}{c}\text { (5) } \\
\text { Employer } \\
\text { Match }\end{array}$ \\
\hline \multirow[t]{2}{*}{ Video } & 0.089 & 0.036 & 0.100 & 0.144 & 0.063 \\
\hline & $(0.012)^{* *}$ & $(0.016)^{*}$ & $(0.013) * *$ & $(0.014)^{* *}$ & $(0.012)^{* *}$ \\
\hline \multirow[t]{2}{*}{ Narrative } & 0.076 & -0.004 & 0.094 & 0.128 & 0.061 \\
\hline & $(0.012)^{* *}$ & $(0.016)$ & $(0.013)^{* *}$ & $(0.014)^{* *}$ & $(0.012)^{* *}$ \\
\hline \multirow[t]{2}{*}{ Both } & 0.095 & 0.031 & 0.105 & 0.144 & 0.080 \\
\hline & $(0.015)^{* *}$ & $(0.020)$ & $(0.015)^{* *}$ & $(0.016) * *$ & $(0.015)^{* *}$ \\
\hline \multirow[t]{2}{*}{ Has credit card debt } & 0.009 & 0.013 & -0.003 & -0.003 & -0.007 \\
\hline & $(0.009)$ & $(0.012)$ & $(0.010)$ & $(0.010)$ & $(0.009)$ \\
\hline \multirow[t]{2}{*}{$41-64$} & 0.059 & 0.003 & 0.040 & 0.086 & 0.020 \\
\hline & $(0.011)^{* *}$ & $(0.014)$ & $(0.011)^{* *}$ & $(0.012)^{* *}$ & $(0.011)$ \\
\hline \multirow[t]{2}{*}{$65+$} & 0.064 & -0.022 & 0.071 & 0.072 & -0.003 \\
\hline & $(0.014)^{* *}$ & $(0.019)$ & $(0.015)^{* *}$ & $(0.016)^{* *}$ & $(0.014)$ \\
\hline \multirow{2}{*}{$\begin{array}{l}\text { Some college/ } \\
\text { Associate Degree }\end{array}$} & 0.060 & 0.058 & 0.082 & 0.052 & 0.060 \\
\hline & $(0.013)^{* *}$ & $(0.017)^{* *}$ & $(0.013)^{* *}$ & $(0.014)^{* *}$ & $(0.013)^{* *}$ \\
\hline \multirow[t]{2}{*}{ College Degree } & 0.102 & 0.103 & 0.091 & 0.083 & 0.096 \\
\hline & $(0.013)^{* *}$ & $(0.018)^{* *}$ & $(0.014)^{* *}$ & $(0.015)^{* *}$ & $(0.013)^{* *}$ \\
\hline \multirow[t]{2}{*}{ Female } & -0.013 & -0.031 & -0.013 & -0.020 & -0.002 \\
\hline & $(0.009)$ & $(0.012)^{*}$ & $(0.010)$ & $(0.011)$ & $(0.009)$ \\
\hline \multirow[t]{2}{*}{$\$ 35 \mathrm{~K}-\$ 75 \mathrm{~K}$} & 0.030 & 0.041 & 0.067 & 0.068 & 0.052 \\
\hline & $(0.012)^{*}$ & $(0.015)^{* *}$ & $(0.012)^{* *}$ & $(0.013)^{* *}$ & $(0.012)^{* *}$ \\
\hline \multirow[t]{2}{*}{$>\$ 75 \mathrm{~K}$} & 0.053 & 0.067 & 0.079 & 0.062 & 0.078 \\
\hline & $(0.013)^{* *}$ & $(0.017)^{* *}$ & $(0.013)^{* *}$ & $(0.015)^{* *}$ & $(0.013)^{* *}$ \\
\hline Baseline & $\begin{array}{c}0.493 \\
(0.018)^{* *}\end{array}$ & & & & \\
\hline Baseline & & $\begin{array}{c}0.380 \\
(0.019)^{* *}\end{array}$ & & & \\
\hline Baseline & & & $\begin{array}{c}0.445 \\
(0.016)^{* *}\end{array}$ & & \\
\hline Baseline & & & & & $\begin{array}{c}0.407 \\
(0.016)^{* *}\end{array}$ \\
\hline Constant & $\begin{array}{c}0.231 \\
(0.021)^{* *}\end{array}$ & $\begin{array}{c}0.372 \\
(0.027)^{* *}\end{array}$ & $\begin{array}{c}0.266 \\
(0.020)^{* *}\end{array}$ & $\begin{array}{c}0.157 \\
(0.020)^{* *}\end{array}$ & $\begin{array}{c}0.287 \\
(0.019)^{* *}\end{array}$ \\
\hline \multirow[t]{2}{*}{$\begin{array}{l}\text { Tax-Favored Assets, } \\
\text { Baseline }\end{array}$} & & & & 0.441 & \\
\hline & & & & $(0.018)^{* *}$ & \\
\hline Observations & 2275 & 2298 & 2285 & 2279 & 2302 \\
\hline R-squared & 0.38 & 0.21 & 0.40 & 0.37 & 0.35 \\
\hline
\end{tabular}


Table 5: Treatment effects on changes in knowledge $\left(\mathrm{Y}_{1^{-}}-\mathrm{Y}_{0}\right)$.

\begin{tabular}{lccccc}
\hline & $\begin{array}{c}(1) \\
\text { Compound } \\
\text { Interest }\end{array}$ & $\begin{array}{c}(2) \\
\text { Inflation }\end{array}$ & $\begin{array}{c}(3) \\
\text { Risk } \\
\text { Diversification }\end{array}$ & $\begin{array}{c}\text { Tax-Favored } \\
\text { Assets }\end{array}$ & $\begin{array}{c}(5) \\
\text { Employer } \\
\text { Match }\end{array}$ \\
\hline Video & 0.098 & 0.044 & 0.101 & 0.150 & 0.063 \\
& $(0.014)^{* *}$ & $(0.020)^{*}$ & $(0.016)^{* *}$ & $(0.017)^{* *}$ & $(0.016)^{* *}$ \\
Narrative & 0.075 & -0.011 & 0.102 & 0.139 & 0.066 \\
& $(0.014)^{* *}$ & $(0.020)$ & $(0.016)^{* *}$ & $(0.017)^{* *}$ & $(0.015)^{* *}$ \\
Both & 0.094 & 0.017 & 0.106 & 0.158 & 0.078 \\
& $(0.018)^{* *}$ & $(0.024)$ & $(0.019)^{* *}$ & $(0.019)^{* *}$ & $(0.019)^{* *}$ \\
Has Credit Card & 0.016 & 0.015 & -0.008 & 0.001 & -0.016 \\
Debt & & & & $(0.012)$ & $(0.012)$ \\
& $(0.011)$ & $(0.015)$ & $(0.012)$ & -0.014 \\
41-64 & 0.037 & -0.001 & -0.032 & 0.016 & $(0.013)$ \\
& $(0.012)^{* *}$ & $(0.017)$ & $(0.014)^{*}$ & $(0.015)$ & -0.050 \\
65+ & 0.018 & -0.013 & -0.030 & -0.025 & $(0.018)^{* *}$ \\
Some College/ & $(0.016)$ & $(0.023)$ & $(0.018)$ & $(0.019)$ & 0.020 \\
Associate Degree & 0.014 & 0.020 & 0.036 & 0.017 & $(0.016)$ \\
& & & & \\
College Degree & $(0.015)$ & $(0.020)$ & $(0.016)^{*}$ & $(0.017)$ & -0.003 \\
& 0.015 & 0.030 & -0.012 & -0.008 & $(0.016)$ \\
Female & $(0.015)$ & $(0.021)$ & $(0.017)$ & $(0.018)$ & 0.041 \\
& 0.032 & -0.012 & 0.039 & 0.019 & $(0.012)^{* *}$ \\
\$35K-\$75K & $(0.011)^{* *}$ & $(0.015)$ & $(0.012)^{* *}$ & $(0.013)$ & -0.016 \\
& -0.010 & 0.006 & 0.007 & 0.011 & $(0.014)$ \\
\$ \$75K & $(0.013)$ & $(0.019)$ & $(0.015)$ & $(0.016)$ & -0.029 \\
Constant & -0.006 & -0.000 & 0.006 & -0.034 & $(0.016)$ \\
Observations & $(0.015)$ & $(0.021)$ & $(0.016)$ & $(0.017)^{*}$ & -0.040 \\
R-squared & -0.083 & -0.033 & -0.018 & -0.019 & $(0.022)$ \\
& $(0.020)^{* *}$ & $(0.028)$ & $(0.022)$ & $(0.024)$ & 0.02 \\
\hline
\end{tabular}


Table 6: Treatment regressions on self-efficacy $\left(Y_{1}\right)$.

\begin{tabular}{|c|c|c|c|c|c|}
\hline & $\begin{array}{c}(1) \\
\text { Compound } \\
\text { Interest }\end{array}$ & $\begin{array}{c}(2) \\
\text { Inflation }\end{array}$ & $\begin{array}{c}(3) \\
\text { Risk } \\
\text { Diversification }\end{array}$ & $\begin{array}{c}(4) \\
\text { Tax- Favored } \\
\text { Assets }\end{array}$ & $\begin{array}{c}\text { (5) } \\
\text { Employer } \\
\text { Match }\end{array}$ \\
\hline \multirow[t]{2}{*}{ Video } & -0.662 & -0.598 & -0.603 & -0.869 & -0.943 \\
\hline & $(0.049)^{* *}$ & $(0.046)^{* *}$ & $(0.046)^{* *}$ & $(0.052)^{* *}$ & $(0.053)^{* *}$ \\
\hline \multirow[t]{2}{*}{ Narrative } & -0.344 & -0.310 & -0.488 & -0.642 & -0.817 \\
\hline & $(0.048)^{* *}$ & $(0.045)^{* *}$ & $(0.046)^{* *}$ & $(0.052) * *$ & $(0.053)^{* *}$ \\
\hline \multirow{2}{*}{ Both } & -0.659 & -0.464 & -0.640 & -0.937 & -1.093 \\
\hline & $(0.061)^{* *}$ & $(0.056)^{* *}$ & $(0.055)^{* *}$ & $(0.061)^{* *}$ & $(0.064)^{* *}$ \\
\hline \multirow{2}{*}{$\begin{array}{l}\text { Has Credit Card } \\
\text { Debt }\end{array}$} & 0.135 & 0.067 & 0.035 & 0.063 & -0.054 \\
\hline & $(0.037)^{* *}$ & $(0.034)^{*}$ & $(0.035)$ & $(0.039)$ & $(0.040)$ \\
\hline \multirow[t]{2}{*}{$41-64$} & -0.029 & -0.040 & -0.051 & -0.074 & -0.077 \\
\hline & $(0.043)$ & $(0.040)$ & $(0.040)$ & $(0.046)$ & $(0.046)$ \\
\hline \multirow[t]{2}{*}{$65+$} & -0.013 & -0.072 & -0.059 & 0.055 & 0.157 \\
\hline & $(0.056)$ & $(0.053)$ & $(0.053)$ & $(0.060)$ & $(0.061)^{*}$ \\
\hline \multirow{2}{*}{$\begin{array}{l}\text { Some College/ } \\
\text { Associate Degree }\end{array}$} & -0.144 & -0.001 & -0.149 & -0.168 & -0.215 \\
\hline & $(0.050)^{* *}$ & $(0.047)$ & $(0.047)^{* *}$ & $(0.054)^{* *}$ & $(0.054)^{* *}$ \\
\hline \multirow[t]{2}{*}{ College Degree } & -0.314 & -0.037 & -0.249 & -0.313 & -0.219 \\
\hline & $(0.052)^{* *}$ & $(0.049)$ & $(0.049)^{* *}$ & $(0.056)^{* *}$ & $(0.057)^{* *}$ \\
\hline \multirow[t]{2}{*}{ Female } & 0.261 & 0.014 & 0.194 & 0.122 & 0.078 \\
\hline & $(0.037)^{* *}$ & $(0.035)$ & $(0.036) * *$ & $(0.040)^{* *}$ & $(0.041)$ \\
\hline \multirow[t]{2}{*}{$\$ 35 \mathrm{~K}-\$ 75 \mathrm{~K}$} & -0.178 & -0.032 & -0.066 & -0.259 & -0.225 \\
\hline & $(0.046)^{* *}$ & $(0.042)$ & $(0.043)$ & $(0.049)^{* *}$ & $(0.050)^{* *}$ \\
\hline \multirow[t]{2}{*}{$>\$ 75 \mathrm{~K}$} & -0.311 & -0.102 & -0.148 & -0.387 & -0.350 \\
\hline & $(0.051)^{* *}$ & $(0.047)^{*}$ & $(0.048)^{* *}$ & $(0.054) * *$ & $(0.055)^{* *}$ \\
\hline \multirow[t]{2}{*}{ Baseline Score } & 0.350 & 0.363 & 0.354 & 0.324 & 0.316 \\
\hline & $(0.018)^{* *}$ & $(0.018)^{* *}$ & $(0.018)^{* *}$ & $(0.021)^{* *}$ & $(0.019)^{* *}$ \\
\hline \multirow[t]{2}{*}{ Constant } & 2.041 & 1.780 & 2.001 & 2.311 & 2.273 \\
\hline & $(0.085)^{* *}$ & $(0.082)^{* *}$ & $(0.085)^{* *}$ & $(0.100)^{* *}$ & $(0.093)^{* *}$ \\
\hline Observations & 2315 & 2326 & 2313 & 2312 & 2345 \\
\hline R-squared & 0.31 & 0.22 & 0.29 & 0.28 & 0.29 \\
\hline $\mathrm{p}$ video $=$ narr & 0.00 & 0.00 & 0.01 & 0.00 & 0.01 \\
\hline $\mathrm{p}$ both $=$ narrative & 0.00 & 0.00 & 0.00 & 0.00 & 0.00 \\
\hline $\mathrm{p}$ video $=$ both & 0.97 & 0.01 & 0.48 & 0.25 & 0.02 \\
\hline
\end{tabular}


Table 7: Treatment effects on changes in self-efficacy $\left(Y_{1}-Y_{\theta}\right)$

\begin{tabular}{|c|c|c|c|c|c|}
\hline & $\begin{array}{c}\text { (1) } \\
\text { Compound } \\
\text { Interest }\end{array}$ & $\begin{array}{c}\text { (2) } \\
\text { Inflation }\end{array}$ & $\begin{array}{c}(3) \\
\text { Risk Diversification }\end{array}$ & $\begin{array}{c}(4) \\
\text { Tax-Favored } \\
\text { Assets }\end{array}$ & $\begin{array}{c}(5) \\
\text { Employer } \\
\text { Match }\end{array}$ \\
\hline \multirow[t]{2}{*}{ Video } & -0.620 & -0.694 & -0.587 & -0.871 & -0.987 \\
\hline & $(0.062)^{* *}$ & $(0.057)^{* *}$ & $(0.057)^{* *}$ & $(0.063)^{* *}$ & $(0.066)^{* *}$ \\
\hline \multirow{2}{*}{ Narrative } & -0.296 & -0.336 & -0.455 & -0.688 & -0.869 \\
\hline & $(0.061)^{* *}$ & $(0.056)^{* *}$ & $(0.058)^{* *}$ & $(0.063)^{* *}$ & $(0.066)^{* *}$ \\
\hline \multirow[t]{2}{*}{ Both } & -0.675 & -0.502 & -0.650 & -1.009 & -1.058 \\
\hline & $(0.077)^{* *}$ & $(0.069)^{* *}$ & $(0.068) * *$ & $(0.073)^{* *}$ & $(0.079)^{* *}$ \\
\hline \multirow[t]{2}{*}{ Has Credit Card Debt } & -0.000 & -0.040 & -0.094 & -0.037 & -0.158 \\
\hline & $(0.046)$ & $(0.042)$ & $(0.043)^{*}$ & $(0.047)$ & $(0.049)^{* *}$ \\
\hline \multirow[t]{2}{*}{$41-64$} & -0.002 & 0.072 & -0.032 & -0.034 & -0.017 \\
\hline & $(0.054)$ & $(0.050)$ & $(0.050)$ & $(0.055)$ & $(0.057)$ \\
\hline \multirow[t]{2}{*}{$65+$} & 0.069 & 0.088 & 0.063 & 0.185 & 0.277 \\
\hline & $(0.071)$ & $(0.065)$ & $(0.066)$ & $(0.073)^{*}$ & $(0.076) * *$ \\
\hline \multirow{2}{*}{$\begin{array}{l}\text { Some College/ } \\
\text { Associate Degree }\end{array}$} & -0.033 & 0.062 & -0.047 & -0.097 & -0.167 \\
\hline & $(0.063)$ & $(0.058)$ & $(0.059)$ & $(0.065)$ & $(0.068) *$ \\
\hline \multirow[t]{2}{*}{ College degree } & -0.131 & 0.110 & 0.024 & -0.089 & -0.014 \\
\hline & $(0.066)^{*}$ & $(0.061)$ & $(0.061)$ & $(0.067)$ & $(0.070)$ \\
\hline \multirow[t]{2}{*}{ Female } & 0.018 & -0.220 & -0.083 & -0.111 & -0.206 \\
\hline & $(0.047)$ & $(0.043)^{* *}$ & $(0.043)$ & $(0.047)^{*}$ & $(0.050)^{* *}$ \\
\hline \multirow[t]{2}{*}{$\$ 35 \mathrm{~K}-\$ 75 \mathrm{~K}$} & -0.092 & -0.039 & -0.014 & -0.187 & -0.080 \\
\hline & $(0.057)$ & $(0.053)$ & $(0.054)$ & $(0.059)^{* *}$ & $(0.062)$ \\
\hline \multirow[t]{2}{*}{$>\$ 75 \mathrm{~K}$} & -0.160 & -0.038 & -0.001 & -0.196 & -0.064 \\
\hline & $(0.064) *$ & $(0.059)$ & $(0.060)$ & $(0.065)^{* *}$ & $(0.068)$ \\
\hline \multirow[t]{2}{*}{ Constant } & 0.224 & -0.023 & 0.034 & 0.181 & 0.270 \\
\hline & $(0.087)^{*}$ & $(0.081)$ & $(0.082)$ & $(0.090)^{*}$ & $(0.093)^{* *}$ \\
\hline Observations & 2315 & 2326 & 2313 & 2312 & 2345 \\
\hline R-squared & 0.06 & 0.08 & 0.06 & 0.12 & 0.13 \\
\hline $\mathrm{p}$ video $=$ narrative & 0.00 & 0.00 & 0.02 & 0.00 & 0.06 \\
\hline $\mathrm{p}$ both $=$ narrative & 0.00 & 0.01 & 0.00 & 0.00 & 0.01 \\
\hline p video $=$ both & 0.45 & 0.00 & 0.33 & 0.05 & 0.36 \\
\hline
\end{tabular}


Table 8: Treatment effects on changes in knowledge $\left(\mathrm{Y}_{2}-\mathrm{Y}_{0}\right)$.

\begin{tabular}{lccccc}
\hline & $\begin{array}{c}(1) \\
\text { Compound } \\
\text { Interest }\end{array}$ & $\begin{array}{c}(2) \\
\text { Inflation }\end{array}$ & $\begin{array}{c}(3) \\
\text { Risk } \\
\text { Diversification }\end{array}$ & $\begin{array}{c}\text { Tax-Favored } \\
\text { Assets }\end{array}$ & $\begin{array}{c}\text { Employer } \\
\text { Match }\end{array}$ \\
\hline Video & 0.041 & 0.042 & 0.032 & 0.031 & 0.008 \\
Narrative & $(0.014)^{* *}$ & $(0.020)^{*}$ & $(0.015)^{*}$ & $(0.015)^{*}$ & $(0.015)$ \\
& 0.008 & 0.032 & 0.033 & 0.034 & 0.020 \\
Both & $(0.014)$ & $(0.020)$ & $(0.015)^{*}$ & $(0.015)^{*}$ & $(0.015)$ \\
& 0.034 & 0.010 & 0.034 & 0.033 & 0.021 \\
Credit card debt & $(0.017)$ & $(0.025)$ & $(0.018)$ & $(0.018)$ & $(0.018)$ \\
& 0.005 & 0.030 & -0.001 & -0.011 & -0.023 \\
41-64 & $(0.011)$ & $(0.015)^{*}$ & $(0.012)$ & $(0.011)$ & $(0.011)^{*}$ \\
& 0.006 & -0.001 & -0.017 & 0.006 & 0.013 \\
65+ & $(0.012)$ & $(0.018)$ & $(0.014)$ & $(0.013)$ & $(0.013)$ \\
& -0.017 & -0.022 & -0.023 & -0.022 & 0.019 \\
Some College/ & $(0.016)$ & $(0.023)$ & $(0.018)$ & $(0.018)$ & $(0.017)$ \\
Associate Degree & 0.007 & -0.007 & -0.000 & 0.004 & 0.019 \\
& & & & & \\
College Degree & $(0.015)$ & $(0.021)$ & $(0.016)$ & $(0.016)$ & $(0.015)$ \\
& 0.009 & -0.001 & -0.015 & -0.009 & 0.005 \\
Female & $(0.015)$ & $(0.022)$ & $(0.017)$ & $(0.016)$ & $(0.016)$ \\
& 0.000 & -0.023 & 0.013 & -0.010 & 0.024 \\
\$35K-\$75K & $(0.011)$ & $(0.015)$ & $(0.012)$ & $(0.012)$ & $(0.011)^{*}$ \\
& 0.006 & 0.010 & -0.017 & 0.008 & 0.004 \\
> \$75K & $(0.013)$ & $(0.019)$ & $(0.015)$ & $(0.014)$ & $(0.014)$ \\
& -0.003 & -0.007 & -0.001 & -0.014 & -0.012 \\
Constant & $(0.015)$ & $(0.021)$ & $(0.016)$ & $(0.016)$ & $(0.015)$ \\
& -0.031 & -0.033 & 0.029 & 0.040 & -0.001 \\
Observations & $(0.020)$ & $(0.028)$ & $(0.022)$ & $(0.021)$ & $(0.021)$ \\
\cline { 2 - 6 } R-sq & 2454 & 2457 & 2455 & 2448 & 2446 \\
Standard errors in parentheses & 0.006 & 0.006 & 0.005 & 0.006 & 0.006 \\
\hline
\end{tabular}


Table 9: Treatment regressions on changes in self-efficacy $\left(\mathrm{Y}_{2^{-}} \mathrm{Y}_{0}\right)$.

\begin{tabular}{|c|c|c|c|c|c|}
\hline & $\begin{array}{c}\text { (1) } \\
\text { Compound } \\
\text { Interest }\end{array}$ & $\begin{array}{c}(2) \\
\text { Inflation }\end{array}$ & $\begin{array}{c}\text { (3) } \\
\text { Risk } \\
\text { Diversification }\end{array}$ & $\begin{array}{c}(4) \\
\text { Tax-Favored } \\
\text { Assets }\end{array}$ & $\begin{array}{c}\text { (5) } \\
\text { Employer } \\
\text { Match }\end{array}$ \\
\hline Video & $\begin{array}{l}-0.045 \\
(0.057)\end{array}$ & $\begin{array}{c}-0.187 \\
(0.051)^{*}\end{array}$ & $\begin{array}{c}-0.084 \\
(0.051)\end{array}$ & $\begin{array}{c}-0.107 \\
(0.051)^{*}\end{array}$ & $\begin{array}{c}-0.166 \\
(0.056) * *\end{array}$ \\
\hline Narrative & $\begin{array}{c}-0.064 \\
(0.056)\end{array}$ & $\begin{array}{c}-0.123 \\
(0.050)^{*}\end{array}$ & $\begin{array}{l}-0.015 \\
(0.051)\end{array}$ & $\begin{array}{c}-0.151 \\
(0.051)^{* *}\end{array}$ & $\begin{array}{l}-0.093 \\
(0.055)\end{array}$ \\
\hline Both & $\begin{array}{c}-0.078 \\
(0.071)\end{array}$ & $\begin{array}{c}-0.174 \\
(0.063)^{*}\end{array}$ & $\begin{array}{c}-0.102 \\
(0.060)\end{array}$ & $\begin{array}{c}-0.053 \\
(0.061)\end{array}$ & $\begin{array}{l}-0.098 \\
(0.067)\end{array}$ \\
\hline Has credit card debt & $\begin{array}{c}0.003 \\
(0.043)\end{array}$ & $\begin{array}{c}0.010 \\
(0.039)\end{array}$ & $\begin{array}{c}-0.021 \\
(0.039)\end{array}$ & $\begin{array}{c}0.049 \\
(0.039)\end{array}$ & $\begin{array}{l}-0.026 \\
(0.042)\end{array}$ \\
\hline $41-64$ & $\begin{array}{l}-0.019 \\
(0.050)\end{array}$ & $\begin{array}{c}0.078 \\
(0.045)\end{array}$ & $\begin{array}{c}0.033 \\
(0.045)\end{array}$ & $\begin{array}{c}0.039 \\
(0.045)\end{array}$ & $\begin{array}{l}-0.057 \\
(0.049)\end{array}$ \\
\hline $65+$ & $\begin{array}{c}-0.036 \\
(0.067)\end{array}$ & $\begin{array}{c}0.115 \\
(0.060)\end{array}$ & $\begin{array}{c}0.110 \\
(0.059)\end{array}$ & $\begin{array}{c}0.057 \\
(0.060)\end{array}$ & $\begin{array}{c}0.009 \\
(0.065)\end{array}$ \\
\hline Some college/Associate & $\begin{array}{c}0.057 \\
(0.060)\end{array}$ & $\begin{array}{c}0.031 \\
(0.054)\end{array}$ & $\begin{array}{c}0.018 \\
(0.053)\end{array}$ & $\begin{array}{c}-0.012 \\
(0.054)\end{array}$ & $\begin{array}{c}-0.120 \\
(0.058)^{*}\end{array}$ \\
\hline College Degree & $\begin{array}{c}-0.063 \\
(0.062)\end{array}$ & $\begin{array}{l}-0.045 \\
(0.055)\end{array}$ & $\begin{array}{c}0.003 \\
(0.055)\end{array}$ & $\begin{array}{c}0.062 \\
(0.056)\end{array}$ & $\begin{array}{l}-0.062 \\
(0.061)\end{array}$ \\
\hline Female & $\begin{array}{c}0.015 \\
(0.044)\end{array}$ & $\begin{array}{c}0.052 \\
(0.039)\end{array}$ & $\begin{array}{c}0.033 \\
(0.039)\end{array}$ & $\begin{array}{c}0.051 \\
(0.039)\end{array}$ & $\begin{array}{l}-0.001 \\
(0.043)\end{array}$ \\
\hline$\$ 35 \mathrm{~K}-\$ 75 \mathrm{~K}$ & $\begin{array}{c}0.064 \\
(0.054)\end{array}$ & $\begin{array}{c}0.011 \\
(0.048)\end{array}$ & $\begin{array}{l}-0.019 \\
(0.048)\end{array}$ & $\begin{array}{c}0.008 \\
(0.049)\end{array}$ & $\begin{array}{c}0.006 \\
(0.053)\end{array}$ \\
\hline$>\$ 75 \mathrm{~K}$ & $\begin{array}{c}-0.010 \\
(0.060)\end{array}$ & $\begin{array}{c}0.007 \\
(0.054)\end{array}$ & $\begin{array}{c}-0.026 \\
(0.054)\end{array}$ & $\begin{array}{c}0.013 \\
(0.054)\end{array}$ & $\begin{array}{c}0.020 \\
(0.059)\end{array}$ \\
\hline Constant & $\begin{array}{c}-0.024 \\
(0.081)\end{array}$ & $\begin{array}{c}-0.062 \\
(0.072)\end{array}$ & $\begin{array}{c}-0.079 \\
(0.072)\end{array}$ & $\begin{array}{l}-0.132 \\
(0.072)\end{array}$ & $\begin{array}{c}0.053 \\
(0.079)\end{array}$ \\
\hline Observations & 2478 & 2458 & 2454 & 2452 & 2449 \\
\hline R-sq & 0.005 & 0.010 & 0.004 & 0.007 & 0.006 \\
\hline Standard errors in & $* \mathrm{p}<0.05$ & $<0.01$ & $\mathrm{p}<0.001$ & & \\
\hline
\end{tabular}


Table 10: Comparison of short term and long term effects

\begin{tabular}{|c|c|c|c|c|c|}
\hline & $\begin{array}{l}\text { Compound } \\
\text { Interest }\end{array}$ & Inflation & $\begin{array}{c}\text { Risk } \\
\text { Diversification }\end{array}$ & $\begin{array}{l}\text { Tax- } \\
\text { Favored } \\
\text { Assets }\end{array}$ & $\begin{array}{l}\text { Employer } \\
\text { Match }\end{array}$ \\
\hline \multicolumn{6}{|c|}{ Knowledge Effects } \\
\hline \multicolumn{6}{|c|}{$Y_{1}-Y_{0}$} \\
\hline Video & 0.098 & 0.044 & 0.101 & 0.15 & 0.063 \\
\hline Narrative & 0.075 & -0.011 & 0.102 & 0.139 & 0.066 \\
\hline Both & 0.094 & 0.017 & 0.106 & 0.158 & 0.078 \\
\hline \multicolumn{6}{|c|}{$Y_{2}-Y_{0}$} \\
\hline Video & 0.041 & 0.042 & 0.032 & 0.031 & 0.008 \\
\hline Narrative & 0.008 & 0.032 & 0.033 & 0.034 & 0.02 \\
\hline Both & 0.034 & 0.01 & 0.034 & 0.033 & 0.021 \\
\hline \multicolumn{6}{|c|}{$\left(\mathbf{Y}_{2}-\mathbf{Y}_{0}\right) /\left(\mathbf{Y}_{1}-\mathbf{Y}_{0}\right)$} \\
\hline Video & $42 \%$ & $95 \%$ & $32 \%$ & $21 \%$ & $13 \%$ \\
\hline Narrative & $11 \%$ & - & $32 \%$ & $24 \%$ & $30 \%$ \\
\hline Both & $36 \%$ & $59 \%$ & $32 \%$ & $21 \%$ & $27 \%$ \\
\hline \multicolumn{6}{|c|}{ Effects on Self-Efficacy } \\
\hline \multicolumn{6}{|c|}{$Y_{1-} Y_{0}$} \\
\hline Video & -0.62 & -0.694 & -0.587 & -0.871 & -0.987 \\
\hline Narrative & -0.296 & -0.336 & -0.455 & -0.688 & -0.869 \\
\hline Both & -0.675 & -0.502 & -0.65 & -1.009 & -1.058 \\
\hline \multicolumn{6}{|c|}{$\mathbf{Y}_{2}-\mathbf{Y}_{0}$} \\
\hline Video & -0.045 & -0.187 & -0.084 & -0.107 & -0.166 \\
\hline Narrative & -0.064 & -0.123 & -0.015 & -0.151 & -0.093 \\
\hline Both & -0.078 & -0.174 & -0.102 & -0.053 & -0.098 \\
\hline \multicolumn{6}{|c|}{$\left(\mathbf{Y}_{2}-\mathbf{Y}_{0}\right) /\left(\mathbf{Y}_{1}-\mathbf{Y}_{0}\right)$} \\
\hline Video & $7 \%$ & $27 \%$ & $14 \%$ & $12 \%$ & $17 \%$ \\
\hline Narrative & $22 \%$ & $37 \%$ & $3 \%$ & $22 \%$ & $11 \%$ \\
\hline Both & $12 \%$ & $35 \%$ & $16 \%$ & $5 \%$ & $9 \%$ \\
\hline
\end{tabular}




\section{Appendix A: Financial Literacy Baseline Survey}

Today we would like to ask you some questions about financial decision making. You may have previously answered a number of questions that you will be asked today. Please answer all the questions you are asked to the best of your ability, even if you have seen them before. We are very interested in your responses, as some of your information and perceptions may have changed. Thank you!

CI1 self-efficacy about interest rates

When making decisions about personal finances, how likely is it that you would be able to effectively take into account the impact of interest compounding?

1 Extremely likely

2 Very likely

3 Somewhat likely

4 Very unlikely

5 Extremely unlikely

CI2 knowledge of interest on interest

Suppose you put $\$ 1,000$ in an account that earns 5\% interest per year, every year. You never invest additional money and you never withdraw money or interest payments. So in the first year, you earn $\$ 50$ in interest. In Year 4, how much will this account earn?

1 Less than $\$ 50$

$2 \$ 50$

3 More than $\$ 50$

4 Don't know

CI3 knowledge of 7 and 10 rule

Suppose you invest $\$ 2,500$ and earn $7 \%$ per year on this investment. How many years will it take for your total investment to be worth $\$ 5,000$ ?

1 Between 0 and 5 years

2 Between 5 and 15 years

3 Between 15 and 45 years

4 More than 45 years

5 Don't know

CI4 behavior regarding earning over time

Consider the following scenario: Jack and Jill are twins. At the age of 20, Jack started contributing \$20 a month to a savings account. After 20 years, at the age of 40, he stopped adding to his savings, but he left the money in the account. Jill didn't start to save until she was 40. Then, she saved $\$ 20$ a month until she retired 20 years later at age 60. Suppose both Jack and Jill earned $6 \%$ interest per year on their savings. When they both retired at age 60 , who had more money?

1 Jack

2 Jill

3 They had the same amount

4 Don't know 
CI5 behavior regarding earning interest on interest

Pam is deciding between 2 options: Option A: - Invest $\$ 1,000$ in a certificate of deposit that earns 5\% interest. - Pam would not add or remove any money from this investment for the next 30 years. Option B: - Invest $\$ 1,000$ in a savings account that earns 5\% interest.- Move the interest earned on this account every year into a safe at home.- Pam would not add or remove any other money from the savings account or the safe for the next 30 years. At the end of 30 years, which of these options would provide the most money?

1 Option A

2 Option B

3 Pam will have the same amount of money at the end of 30 years regardless of whether she chooses Option A or

Option B.

4 Don't know

I1 self-efficacy about inflation

When making decisions about personal finances, how likely is it that you would be able to effectively take into account the impact of inflation?

1 Extremely likely

2 Very likely

3 Somewhat likely

4 Very unlikely

5 Extremely unlikely

I2 knowledge of inflation

Suppose that by the year 2020 your income has doubled and prices of all goods have doubled too. In 2020, how much will you be able to buy with your 2020 income?

1 More than today

2 The same amount as today

3 Less than today

4 Don't know

I3 behavior regarding inflation

Rita must choose between two job offers. She wants to select the job with a salary that will afford her the higher standard of living for the next few years. Job A offers a 3\% raise every year, while Job B will not provide a raise for the next few years. If Rita chooses Job A, she will live in City A. If Rita chooses Job B, she will live in City B. Rita finds that the price of goods and services today are about the same in both areas. Prices are expected to rise, however, by $4 \%$ in City A every year, and stay the same in City B. Based on her concerns about standard of living, what should Rita do?

1 Take Job A

2 Take Job B

3 Take either one: she will be able to afford the same future standard of living in both places

4 Don't know 
RD1 self-efficacy about risk diversification

When making decisions about personal finances, how likely is it that you would be able to effectively select a mix of investments that reflected your preferred level of risk?

1 Extremely likely

2 Very likely

3 Somewhat likely

4 Very unlikely

5 Extremely unlikely

RD2 knowledge of relationship between risk and return

In general, investments that are riskier tend to provide higher returns over time than

investments with less risk.

1 True

2 False

3 Don't know

RD3 knowledge of risk diversification

Which of the following is an accurate statement about investment returns?

1 Usually, investing $\$ 5,000$ in shares of a single company is safer than investing $\$ 5,000$ in a fund which invests in shares of many companies in multiple industries.

2 Usually, investing $\$ 5,000$ in shares of a single company is less safe than investing $\$ 5,000$ in a fund which

invests in shares of many companies in different industries.

3 Usually, investing $\$ 5,000$ in shares of a single company is equally as safe as investing $\$ 5,000$ in a fund which

invests in shares of many companies in different industries.

4 Don't know

RD4 behavior regarding risk diversification

Suppose you are a member of a stock investment club. This year, the club has about $\$ 200,000$ to invest in stocks and the members prefer not to take a lot of risk. Which of the following strategies would you recommend to your fellow members?

1 Put all of the money in one stock

2 Put all of the money in two stocks

3 Put all of the money in a stock indexed fund that tracks the behavior of 500 large firms in the United States

4 Don't know

TF1 self-efficacy about tax-favored assets

When making decisions about personal finances, how likely is it that you would be able to effectively take advantage of tax-favored investment options available to you?

1 Extremely likely

2 Very likely

3 Somewhat likely

4 Very unlikely

5 Extremely unlikely 
TF2 knowledge of 401(k) taxes

When you invest in an employer's retirement savings plan such as a 401(k), your contributions are taxed:

1 Either before you invest them or when you withdraw them during retirement, but not both times.

2 Both before you invest them and when you withdraw them during retirement.

3 Once a year on or before April 15.

4 When you reach age 65 .

5 Don't know

TF3 knowledge of employer independence

Both Irene and her employer contribute every year to her employer-sponsored 401(k) plan. Irene has worked at the company for twenty years, and is fully vested in her plan. Suppose Irene leaves her job or gets fired. Which of the following statements is true?

1 If she is no longer working for the company, the whole plan balance is forfeited, because her benefits are tied to

her job.

2 If she gets fired, the company has the right to decide how much of her total plan balance she will get.

3 If she voluntarily leaves her job, she forfeits all of her employer's contributions.

4 Even if she leaves her job or gets fired, she is still entitled to the entire plan balance.

5 Don't know

TF4 knowledge of avoiding double taxation

Which of the following statements are true?

1 In any type of IRA or 401(k) account, all of the money in your account grows tax-free.

2 If you have a traditional IRA or 401(k), you make contributions out of pre-tax income and pay income tax at

your future tax rate when you withdraw the funds.

3 Both are true

4 Don't know

TF5 behavior regarding time and rate of taxation

This year, Marge's salary is $\$ 100,000$ and she contributes $\$ 10,000$ of her salary to a traditional $401(\mathrm{k})$ offered by her employer. Her current tax rate is $28 \%$. In 40 years, when Marge retires, the money will have grown to $\$ 160,000$. Her tax rate during retirement will fall to $20 \%$. Which of the following is true?

1 This year, Marge should pay income taxes on her entire salary. During retirement, she will pay $20 \%$ tax on whatever she withdraws from her plan.

2 This year, Marge should pay income taxes on only $\$ 90,000$. During retirement, she will pay the same deferred $28 \%$ tax rate on whatever she withdraws from her plan.

3 This year, Marge should pay income taxes on only $\$ 90,000$. During retirement, she will pay $20 \%$ tax on

whatever she withdraws from her plan.

4 This year, Marge should pay income taxes on only $\$ 90,000$. During retirement, she will pay no tax on whatever 
she withdraws from her plan.

5 Don't know

TF6 behavior regarding assorted 401(k) attributes

Which of the following is a true statement?

1 You will lose money that you personally invested in your 401(k) if you switch jobs.

2 You will be charged income tax as well as tax on dividends and increases in the value of your stock if you invest through a 401(k).

3 Unless you are undergoing significant hardship, you cannot withdraw money from a 401(k) without penalty until you reach a certain age.

4 All of the above

5 Don't know

EM1 self-efficacy about employer match

When making decisions about personal finances, how likely is it that you would be able to effectively use information about employer $401(\mathrm{k})$ matches that was available to you?

1 Extremely likely

2 Very likely

3 Somewhat likely

4 Very unlikely

5 Extremely unlikely

EM2 knowledge of match return equivalent

Alice wants to invest $\$ 1,000$ for retirement this year. Her new employer will fully match her 401(k) contributions, up to $\$ 10,000$ per year. All else being equal, which of the following options will give Alice the highest total amount at the end of the year?

1 Alice contributes $\$ 1,000$ to her $401(\mathrm{k})$ plan and invests that money in mutual fund A. At the end of the year, mutual fund A has earned a $5 \%$ return.

2 Alice does not contribute to her 401(k) plan but she invests $\$ 1,000$ in mutual fund B outside of her $401(\mathrm{k})$ plan. At the end of the year, mutual fund B has earned a $20 \%$ return.

3 Alice does not contribute to her 401(k) plan, but she invests $\$ 1,000$ in mutual fund A outside of her $401(\mathrm{k})$ plan. At the end of the year, mutual fund A has earned a 5\% return. 4 Don't know

EM3 knowledge of match maximization

David's new job offers a $401(\mathrm{k})$. His employer provides a $50 \%$ match up to $\$ 2,000$. How much should David invest at least in order to obtain the maximum amount of money from the employer match?

$1 \$ 0$

$2 \$ 500$

$3 \$ 1,000$

$4 \$ 2,000$

$5 \$ 4,000$

6 Don't know 
EM4 behavior regarding employer match

You have decided to set aside $15 \%$ of your salary for retirement. You work at a firm where your employer

matches your contribution to the $401(\mathrm{k})$ plan, dollar by dollar, up to $5 \%$ of your salary. Which of these statements is correct?

1 If you contribute up to $5 \%$ of your salary, the employer match is equivalent to a $100 \%$ return on your

contribution.

2 What the employer contributes should not play any role in your decision.

$3 \mathrm{It}$ is always a good idea to contribute less than what the employer contributes.

4 Don't know 


\section{Appendix B: The Narratives}

\section{$\underline{\text { A Wedding Gift and Compound Interest }}$}

Dave and Michelle met in college, five years ago. Theirs isn't a romantic story of love at first sight; instead they slowly built the foundation for a strong relationship. Dave asked Michelle out for a coffee, then another, and another. Their relationship continued to grow stronger, and they recently got married.

When they got $\$ 5000$ in cash as wedding presents, Michelle and Dave had to decide what to do with the money. The answer didn't seem obvious. Looking over their finances didn't take long because they didn't have much money, especially since Michelle's job at the time paid more like an internship. The two of them don't generally consider themselves big planners and, at first, it seemed pointless to even think about investing for the long term. Dave suggested not investing right away, but instead waiting until they had better jobs and made more money.

But Michelle told Dave about the 7 and 10 rule. The rule describes how long it takes for an investment to double. At a 7\% rate of return, it takes about 10 years for an investment to grow twice as large. At a $10 \%$ rate of return, it takes only about 7 years to double your money.

\section{7 and 10 Rule}

At a $\mathbf{7 \%}$ rate of return, it takes about $\mathbf{1 0}$ years to double your money. At a $\mathbf{1 0 \%}$ rate of return, it takes about 7 years to double your money.

At first, Dave wondered whether they could get such a high return: $10 \%$ is a lot! Michelle pointed out that a $7 \%$ return might be more realistic. After all, they would be investing for the long term. Dave realized that over the long term a diversified portfolio of stocks can yield returns in that range, though both he and Michelle understand that it always varies.

The simple 7 and 10 rule helped Michelle figure out that even at a $7 \%$ rate of return, the original $\$ 5000$ would grow to a whopping $\$ 160,000$ by the time she and Dave turn 75 . When Michelle first pointed this out to Dave, he thought something had to be wrong with Michelle's calculation. But, as Michelle explained to him, the money grows that much because the returns compound over time. In other words, all of the money, including the earned interest, gets reinvested every year so that over the long term, there's some serious build-up!

If Dave and Michelle earn a 7\% rate of return, their investment would approximately double every 10 years.

If they invest $\mathbf{\$ 5 0 0 0}$ when they are $\mathbf{2 5}$ years old, then:

by age 35 , it would double to around............... $\$ 10,000$

which would double again by age 45 to around ... $\$ 20,000$

which would double again by age 55 to around ...\$40,000

which would double again by age 65 to around ...\$80,000

which would double again by age 75 to around...\$160,000. 
If Michelle and Dave waited until they were 55 years old to invest the $\$ 5,000$ and earned the same $7 \%$ rate of return, they would end up with $\$ 20,000$ by the time they were 75 . And while $\$ 20,000$ would be nice, the $\$ 160,000$ they'd have if they invested right away would be even nicer.

Michelle also showed Dave the other half of the 7 and 10 rule. If their investments perform really well, their money could grow even faster. At a 10\% rate of return, their investment would double in only 7 years. By the time Dave and Michelle reached their mid-70s, their $\$ 5000$ would double a whole bunch of times and turn into $\$ 640,000$ !

Dave and Michelle decided to invest their \$5,000 right away, giving it more time to grow. When their friends and family gave them $\$ 5000$, they never imagined it could turn into six figures. But by applying the 7 and 10 rule, Dave and Michelle realized the money could turn into $\$ 160,000$ or maybe even $\$ 640,000$, for their future. Investing the money was the best wedding gift they could have given themselves! 


\section{Taking Advantage of Employer Matches}

Matt and Josh work at a company that holds a lot of tedious meetings but offers some great perks, like delicious lunches during those meetings. They like free stuff, especially good free stuff like the lunches on meeting days. They like free money even better than free food, so when the coworkers found out that their company matches their $401(\mathrm{k})$ contributions, they had to take advantage of it.

Their employer provides one-to-one matching of employee 401(k) contributions, up to \$2000 a year. For every dollar up to $\$ 2000$ that Matt (or Josh) puts in his $401(\mathrm{k})$, his company puts in a dollar too. It's like an "invest a dollar, get one free" deal. Just like the buy-one-get-one free deals at the deli across the street.

So, if Matt invests $\$ 2000$ of his own money in a $401(\mathrm{k})$ account, then the company puts in the same amount: $\$ 2000$. That would be $\$ 4000$ in his account, because the company matches every dollar. It's like Matt is getting a 100\% return on his investment. Twice as much gets invested and twice as much grows in his account.

At Josh's old job, the company matched $50 \%$ of employee $401(\mathrm{k})$ contributions. His old employer would add half of what Josh put into his $401(\mathrm{k})$. If he invested $\$ 1000$, they'd add $\$ 500$, bringing his account up to $\$ 1500$ before even earning money on investments. That's not as amazing as a one-to-one-match, but it's still a lot of money!

Where Josh and Matt work now, there's something called a vesting schedule. They're "fully vested" after 3 years. That means that after working at the company for 3 years, employees get to keep the entire amount of the employer match in their 401(k) account, even if they leave the company. But no matter what, money that Matt or Josh or any other employee invests in a 401(k), out of their salary, always belongs to the employee. Even if they get fired or decide to leave the job before being fully vested, an employer can't touch the money an employee contributes.

Basically, employer matches are like free money. But if you don't invest in your 401(k), you don't get the match. And if you don't invest the full amount that's eligible for the match, it's like leaving free money on the table. For their part, Matt and Josh aren't trust fund babies. They can't afford to pass up free money! And the buy-one-get-one-free sandwich deal at the deli across the street makes it their favorite spot to go for lunch! 


\section{Don't Put All Your Eggs in One Basket}

As she packs up her grandmother's china for storage, Kate holds up a bowl and reminds her brother Sam that she was always afraid of breaking it when they were kids. Kate and Sam both miss their grandmother, but they each need to decide what they're going to do with the money she left them. Kate tells Sam that she's going to invest her inheritance. She knows their grandmother wanted them to each have a little "nest egg" for the future.

Sam recalls how their grandmother always said, “don't put all your eggs in one basket." For Kate, not putting all your eggs in one basket makes good financial sense and she tells Sam that she's going to spread her inheritance money around.

At first, Sam doesn't understand why just putting your money somewhere safe isn't enough. But, as Kate tells him, when you're investing for the long term, you have to take some risk. Otherwise, there's no way to make your money grow because the average amount of money an investment earns over the long run is related to the riskiness of the investment. Riskier investments tend to make more money, while less risky investments tend to make less money. But that doesn't necessarily mean that riskier investments are better. With riskier investments, there's a chance you'll lose money; there's a trade-off between risk and return.

Kate explains to Sam that each asset in his portfolio, every investment he owns, will have some degree of risk. But what he wants to avoid is having a total wipeout and losing everything he owns all at once. For example, if he owns stock from only one company, then he is betting on the performance of just that one company. If it were totally destroyed, say, by a hurricane, his investment would be in trouble. An individual company can be struck by less dramatic difficulties, too. That's why it's important to invest in a mix of assets and not put all your money in one place.

Sam thinks about what Kate is saying, then tells Kate he's thinking about investing in the company where he works - the company is growing and Sam is confident they're doing well. Kate wonders if he's been listening to her at all! She tells her brother that the whole point of putting his money in a bunch of different assets is that if something unexpectedly bad happens to one of them, he'll be cushioned to a certain degree. But if Sam invested in the company where he works and that company tanked, both his job and his investments would be in trouble. That's where not putting all your eggs in one basket comes in: you shouldn't have your investments and your job tied to the same company, and you shouldn't have all of your money invested in one company. Instead, spread it around.

Kate has Sam consider the following scenario: What if you invested in a whole bunch of companies, but they all manufactured umbrellas and all of a sudden, the value of umbrellas plummeted? That might sound unlikely, but think about when the tech bubble burst or when the real estate market crashed. It's smart to invest in many different kinds of companies and investments. Basically, you want the ups and downs of your investments to be as unrelated to each other as possible so that if some do badly, others will offset those losses. That's why it's a good idea to spread your investments across different countries, too. 
Sam looks at his sister with a warm smile. She really is as smart as their grandmother. As they finish packing up their grandmother's china, Sam is already thinking about ways to go about keeping his "nest egg" of investments in lots of different baskets. 


\section{Inflation and the Plaid Shirt}

This is the story of how a very cute plaid shirt inspired Lisa to save more for the future. Lisa and Beth were shopping together when Beth spotted the shirt and knew it would look great on Lisa. But when Lisa saw it, she had a flashback to the 90's, the last time plaid shirts were trendy. The new shirt cost $\$ 50$ and Lisa remembered paying $\$ 30$ for similar shirts back then. So the word "inflation" popped into Lisa's head.

Inflation describes price increases over time. Lisa realized that not only do shirts that used to cost $\$ 30$ now cost $\$ 50$, but lots of things that used to be $\$ 30$ are now $\$ 50$. When inflation rises, the same number of dollars buys less. So the price of a shirt, and other things like haircuts and groceries, can get higher.

Let's say inflation increases at 4\%. Something that costs $\$ 100$ at the beginning of the year will cost $\$ 104$ at the end of the year. Which doesn't seem like a big deal, until you consider that, on average, everything is going to cost a bit more. If your income doesn't increase, you can't buy as much as you used to because prices are higher. Even if you're making more money than you used to, it still might not be enough if your income didn't increase as much as the cost of what you normally buy.

When Lisa had her plaid shirt "aha" moment, she realized that prices are higher now than they used to be and they're probably going to be even higher in the future. Her friend Beth understood that part, too. But Beth could not figure out how a shirt could go all the way from $\$ 30$ in the 90's to $\$ 50$ now when it doesn't feel like the prices make such huge leaps from one year to the next.

Lisa explained that it's because the price increases build upon one another.

Let's say inflation increases at 3\% every year for 20 years. A $\$ 100$ bag of groceries will cost $\$ 103$ after one year. After 10 years, it will cost $\$ 134$ dollars, and the 3\% just keeps adding up to more and more money so that after 20 years your $\$ 100$ bag of groceries costs $\$ 181$. In other words, your $\$ 100$ groceries cost almost double, closer to $\$ 200,20$ years later.

\section{Cost of Groceries}

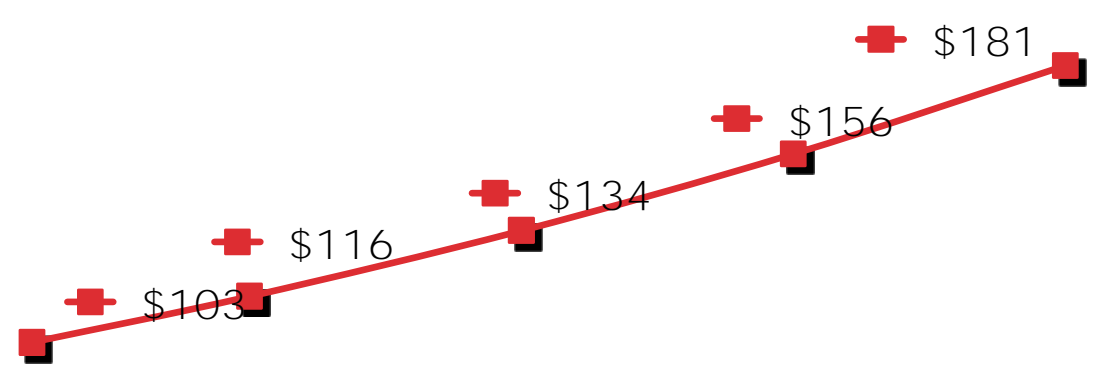

\section{Years}

Lisa knows that when she thinks about how much money she'll need for the future, she needs to consider how much more things will cost. Since her paycheck won't buy as much as it used to, 
she needs to start planning. And if she forgets about inflation, then wearing her cute new shirt will remind her! 


\section{$\underline{\text { Take Advantage of Tax-Free Assets }}$}

It's payday and roommates Becca and Emily are making plans to go out for the evening. Emily touches up her makeup as Becca opens her paycheck, only to discover that while she made $\$ 800$ that week, the check is for only $\$ 640$. She hates how much they take out for taxes!

Emily explains that the reason she signed up for a 401(k) retirement account when she started her new job was to protect her money from getting eaten up by taxes. But Emily's explanation simply confuses Becca, who doesn't understand what a retirement account has to do with taxes.

Emily sits down with her roommate to explain. Everyone pays income tax on their salary. For example, if you're in the $20 \%$ tax bracket, then $20 \%$ of your salary goes to the government and you don't get to use it. But if you start a traditional 401(k) retirement plan, you can contribute pre-tax money to that account. You can contribute a portion of your salary straight to investments, without paying taxes on it, so there's more money for you. With a 401(k), your contributions grow tax-free. You don't pay taxes on the account until you retire, when you probably won't be earning as much and therefore will be taxed in a lower tax bracket.

While this sounds like a good idea, Becca asks what would happen if she wanted to take money out before retirement. Emily explains that if she withdraws money before she is 59 and a half, she will have to pay taxes and will get hit with a penalty fee, too-so it's not usually a good idea.

But the problem for Becca is that she doesn't think her employer offers a 401(k) plan. Emily explains that there are other options. IRAs are another type of retirement account and you don't have to get them through your job; you can get them yourself. As with 401(k)s, there are traditional and Roth varieties. Traditional IRAs protect your money from taxes when you put money in. And Roth IRAs protect your money from some taxes at the end, when you withdraw money during retirement.

Those aren't the only types of retirement accounts available that protect money from taxes. Lots of non-profit and government jobs offer similar types of retirement accounts that work in the same general way as $401(\mathrm{k}) \mathrm{s}$ and IRAs. When you're saving for retirement, it really pays to take advantage of these types of accounts and not give any more away in taxes than you have to! That's why Emily contributes to a 401(k).

Becca and Emily head out the door to their usual happy hour spot, with Becca thinking about how great it is to have friends who can give you financial advice and Emily thinking about whether the cute new bartender will be at happy hour! 
APPENDIX C: Video Links

\begin{tabular}{|c|c|c|}
\hline Topic & Title & Video Link \\
\hline Compound interest & $\begin{array}{l}\text { A Wedding Gift and Compound } \\
\text { Interest }\end{array}$ & www.youtube.com/watch?v=aekR36rxkK8 \\
\hline Inflation & Inflation and the Plaid Shirt & www.youtube.com/watch?v=uuczRBFQU4I \\
\hline Risk diversification & $\begin{array}{l}\text { Don't Put All Your Eggs in One } \\
\text { Basket }\end{array}$ & www.youtube.com/watch?v=l0iF29eQDkU \\
\hline $\begin{array}{l}\text { Tax treatment of } \\
\text { retirement savings } \\
\text { vehicles }\end{array}$ & $\begin{array}{l}\text { Take Advantage of Tax-Free } \\
\text { Assets }\end{array}$ & www.youtube.com/watch?v=C7yRTQ9ffZ0 \\
\hline $\begin{array}{l}\text { Employer matches of } \\
\text { defined contribution } \\
\text { savings plans }\end{array}$ & $\begin{array}{l}\text { Taking Advantage of Employer } \\
\text { Matches }\end{array}$ & www.youtube.com/watch?v=BZEj7wiFarg \\
\hline
\end{tabular}

